\title{
Identification of highly oxygenated organic molecules and their role in aerosol formation in the reaction of limonene with nitrate radical
}

Yindong Guo ${ }^{1}$, Hongru Shen ${ }^{1}$, Iida Pullinen², a, Hao Luo ${ }^{1,3}$, Sungah $\mathrm{Kang}^{2}$, Luc Vereecken², Hendrik Fuchs ${ }^{2}$, Mattias Hallquist ${ }^{4}$, Ismail-Hakki Acir ${ }^{2, b}$, Ralf Tillmann ${ }^{2}$, Franz Rohrer ${ }^{2}$, Jürgen Wildt ${ }^{2}$, Astrid Kiendler-Scharr ${ }^{2}$, Andreas Wahner ${ }^{2}$, Defeng Zhao ${ }^{1,5,6^{*}}$, Thomas F. Mentel ${ }^{2 *}$

${ }^{1}$ Department of Atmospheric and Oceanic Sciences \& Institute of Atmospheric Sciences, Fudan University, 200438, Shanghai, China

${ }^{2}$ Institute of Energy and Climate Research, IEK-8: Troposphere, Forschungszentrum Jülich, 52425, Jülich, Germany ${ }^{3}$ IRDR ICoE on Risk Interconnectivity and Governance on Weather/Climate Extremes Impact and Public Health, Fudan University, Shanghai 200438, China

${ }^{4}$ Department of Chemistry and Molecular biology, University of Gothenburg, Göteborg, 41258, Sweden ${ }^{5}$ Shanghai Frontiers Science Center of Atmosphere-Ocean Interaction, Fudan University, Shanghai 200438, China ${ }^{6}$ Institute of Eco-Chongming (IEC), 20 Cuiniao Rd., Chongming, Shanghai, 202162, China

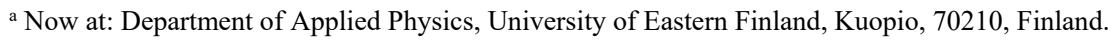

${ }^{b}$ Now at: Institute of Nutrition and Food Sciences, University of Bonn, Bonn, 53115, Germany. Correspondence to: Defeng Zhao (dfzhao@fudan.edu.cn), Thomas F. Mentel (t.mentel@fz-juelich.de)

Abstract. Nighttime nitrate radical $\left(\mathrm{NO}_{3}\right)$-initiated oxidation of biogenic volatile organic compounds (BVOC) such as monoterpenes is important for the formation and growth of secondary organic aerosol (SOA), which has significant impact on climate, air quality and human health. In SOA formation and growth from the oxidation of monoterpenes by $\mathrm{NO}_{3}$, highly oxygenated organic molecules (HOM) may be crucial, but their formation pathways and role in aerosol formation have yet to be clarified. Among monoterpenes, limonene is of research interest for its high emission globally and high SOA yield. In this work, HOM formation in the reaction of limonene with nitrate radical was investigated in the SAPHIR chamber (Simulation of Atmospheric PHotochemistry In a large Reaction chamber). About $280 \mathrm{HOM}$ products were identified, grouped into 6 monomer series (each including 3 families) and one family, 11 dimer families and 3 trimer families. Both closed-shell products and open-shell peroxy radicals $\left(\mathrm{RO}_{2} \bullet\right)$ were observed, and many of them have not been reported previously. Monomers and dimers accounted for over $90 \%$ of HOM concentrations. In the most abundant monomer series $-\mathrm{C}_{10} \mathrm{H}_{15-17} \mathrm{NO}_{6-14}$, carbonyl products outnumbered hydroxyl products, indicating the importance of the unimolecular $\mathrm{RO}_{2} \bullet$ termination pathway. $\mathrm{Both}_{\mathrm{RO}_{2}}$ autoxidation and alkoxy-peroxy pathways were found to be important processes leading to HOM. Time-dependent concentration profiles of monomer products containing nitrogen showed mainly second-generation formation patterns. Dimers were likely formed via the accretion reaction of two monomer $\mathrm{RO}_{2} \bullet$, and $\mathrm{HOM}$-trimers via the accretion reaction between 
monomer $\mathrm{RO}_{2} \bullet$ and dimer $\mathrm{RO}_{2} \bullet$. Trimers are suggested to play an important role in new particle formation (NPF) observed in our experiment. A HOM yield of $1.5 \%(+1.7 \% /-0.7 \%)$ was estimated considering only first-generation products. SOA mass growth could be reasonably explained by HOM condensation on particles assuming irreversible uptake of extremely low volatility organic compounds (ELVOC) and low volatility organic compounds (LVOC). This work provides evidence for the important role of $\mathrm{HOM}$ formed via the limonene $+\mathrm{NO}_{3}$ reaction in $\mathrm{NPF}$ and SOA growth.

\section{Introduction}

The nitrate radical $\left(\mathrm{NO}_{3}\right)$ is an important nighttime oxidant in tropospheric chemistry, and can reach mixing ratios of several hundred pptv during nighttime (Seinfeld and Pandis, 2006). It can react with volatile organic compounds (VOC) and is especially reactive to alkenes, where a nitrate group can be added to $\mathrm{C}=\mathrm{C}$ double bond through addition reaction (Finlayson-Pitts and Pitts, 1997; Seinfeld and Pandis, 2006). Biogenic monoterpene $\left(\mathrm{C}_{10} \mathrm{H}_{16}\right)$ is a large source of alkenes in the atmosphere (Klinger et al., 2002; Guenther et al., 2012), and its major nighttime loss pathway is reacting with $\mathrm{NO}_{3}$ (Beaver et al., 2012; Rollins, 2012; Ayres et al., 2015; Fry et al., 2013). The chemistry of monoterpenes with $\mathrm{NO}_{3}$ has implications on the cycle of reactive nitrogen and thus on ozone formation. Since the $\mathrm{NO}_{3}$ radical is formed through the reaction of $\mathrm{NO}_{2}$ with $\mathrm{O}_{3}$, it is considered to be anthropogenic origin, and reactions of $\mathrm{NO}_{3}$ with biogenic $\mathrm{VOC}(\mathrm{BVOC})$ represent a typical interaction between biogenic emissions and anthropogenic emissions.

The reaction of $\mathrm{NO}_{3}$ with monoterpenes can also form secondary organic aerosols (SOA), which can have a large impact on global climate, air quality and human health (Hallquist et al., 2009; Shrivastava et al., 2017). Laboratory studies showed that monoterpenes have high SOA yields in the reaction with $\mathrm{NO}_{3}$ due to the low volatility of oxidation products (Ng et al., 2008; Rollins et al., 2009; Fry et al., 2013; Fry et al., 2014; Ayres et al., 2015; Jokinen et al., 2015; Zhou et al., 2015; Boyd et al., 2015; Nah et al., 2016; Boyd et al., 2017; Slade et al., 2017; Claflin and Ziemann, 2018). Field studies also showed that nighttime $\mathrm{NO}_{3}$-initiated oxidation of monoterpenes contributes significantly to SOA in forested regions influenced by anthropogenic emissions (Pye et al., 2010; Rollins, 2012; Fry et al., 2013; Ayres et al., 2015; Zhou et al., 2015; Xu et al., 2015; Lee et al., 2016; Zhang et al., 2018; Chen et al., 2020) and potentially in urban areas due to the usage of volatile chemical products (VCP) (Nazaroff and Weschler, 2004; Mcdonald et al., 2018). For example, the Southern Oxidant and Aerosol Study (SOAS) showed that the BVOC $+\mathrm{NO}_{3}$ reactions were a substantial source of SOA (Ayres et al., 2015; Xu et al., 2015; Lee et al., 2016; Massoli et al., 
effects require a comprehensive understanding of the reactions of monoterpenes with $\mathrm{NO}_{3}$.

Among all species of monoterpenes, understanding the reaction system of limonene with $\mathrm{NO}_{3}$ is of special importance. The emission of limonene makes the $4^{\text {th }}$ largest contribution with an estimated global emission of 11.4 Tg annually, preceded only by $\alpha$-pinene, $\mathrm{t}$ - $\beta$-ocimene and $\beta$-pinene (Guenther et al., 2012). Besides its biogenic origin, limonene is a common additive in cleaning products (Nazaroff and Weschler, 2004) and can be used as a tracer for fragrances in some places (Gkatzelis et al., 2021). Several studies have shown adverse health effects due to indoor pollution caused by the ozonolysis of limonene (Clausen et al., 2001; Fan et al., 2003; Carslaw et al., 2012; Pagonis et al., 2019). Moreover, limonene stands out with its high reactivity towards the $\mathrm{NO}_{3}$ radical (with a lifetime of 3 min at $298 \mathrm{~K}$ at 20 pptv $\mathrm{NO}_{3}$ ) (Ziemann and Atkinson, 2012), and $\mathrm{NO}_{3}$ oxidation of limonene has high SOA yield (SOA mass yield 15 to $231 \%$ ) (Hallquist et al., 1999; Spittler et al., 2006; Fry et al., 2011; Fry et al., 2014; Boyd et al., 2017; Berkemeier et al., 2020; Mutzel et al., 2021). A number of studies have provided valuable insights into the reaction of limonene with $\mathrm{NO}_{3}$ regarding its $\mathrm{SOA}$ yield, main products and their formation pathways as well as the physicochemical properties of SOA (Peng et al., 2018). For example, Hallquist et al. (1999) measured the SOA mass yield and revealed the dominance of organic nitrates $(\mathrm{ON})$ and carbonyl compounds in the products. Fry et al. (2011) determined the organic nitrate yield and proposed a reaction scheme leading to the formation of organic nitrates and carbonyls, and Fry et al. (2014) compared the SOA and $\mathrm{ON}$ yields from the $\mathrm{NO}_{3}$ oxidation of $\alpha$-pinene, $\beta$-pinene, and limonene, and demonstrated why limonene $+\mathrm{NO}_{3}$ leads to more SOA and $\mathrm{ON}$ than $\alpha$-pinene from a structural perspective. Boyd et al. (2017) found a higher $\mathrm{N}: \mathrm{C}$ ratio of limonene $+\mathrm{NO}_{3} \mathrm{SOA}$ than $\beta$-pinene $+\mathrm{NO}_{3} \mathrm{SOA}$. Theoretical investigations have revealed that $\mathrm{NO}_{3}$ addition on the endocyclic $\mathrm{C}=\mathrm{C}$ double bond is more favorable than the exocyclic one due to a lower energy barrier (Jiang et al., 2009). Typically, in the limonene $+\mathrm{NO}_{3}$ reaction, the endocyclic double bond of limonene tends to be attacked by $\mathrm{NO}_{3}$ and leads to products including hydroxysubstituted $\mathrm{ON}$ or diketone products. The remaining exocyclic double bond can also be attacked by $\mathrm{NO}_{3}$ leading to more functionalized products (Fry et al., 2011).

Recently, a class of compounds named highly oxygenated organic molecules (HOM) have been shown to be critical substances in the SOA formation from BVOC oxidation, particularly monoterpenes, featuring high oxidation degree, high O/C ratio and low to extremely low volatility (Ehn et al., 2014; Tröstl et al., 2016; Kirkby et al., 2016; Bianchi et al., 2019). HOM here refers to organic compounds which are formed in the gas phase via autoxidation and contain at least six oxygen atoms (Bianchi et al., 2019). The formation of HOM via autoxidation involves a sequence of multiple intramolecular $\mathrm{H}$-shift and $\mathrm{O}_{2}$ addition reactions, and results in highly oxygenated peroxy radicals (HOM$\mathrm{RO}_{2} \bullet$ ) (Ehn et al., 2014). Analogous to "traditional" $\mathrm{RO}_{2} \bullet, \mathrm{HOM}-\mathrm{RO}_{2} \bullet$ can be involved in similar reactions (Bianchi 
et al., 2019). The bimolecular reactions of $\mathrm{HOM}-\mathrm{RO}_{2} \bullet$ with $\mathrm{RO}_{2} \bullet, \mathrm{HO}_{2} \bullet$ and NO lead to highly oxidized products including carbonyls, hydroperoxides, alcohols, organic nitrates as termination groups, or accretion products, as shown in R1 to R4 (Ehn et al., 2014; Mentel et al., 2015):

$$
\begin{gathered}
\mathrm{RO}_{2} \bullet+\mathrm{RO}_{2} \bullet \rightarrow \mathrm{R} \mathrm{H}=\mathrm{O}+\mathrm{ROH}+\mathrm{O}_{2} \\
\mathrm{RO}_{2} \bullet+\mathrm{HO}_{2} \bullet \rightarrow \mathrm{ROOH}+\mathrm{O}_{2} \\
\mathrm{RO}_{2} \bullet+\mathrm{NO} \rightarrow \mathrm{RONO}_{2} \\
\mathrm{RO}_{2} \bullet+\mathrm{RO}_{2} \bullet \rightarrow \mathrm{ROOH}+\mathrm{O}_{2}
\end{gathered}
$$

Unimolecular termination reactions of $\mathrm{HOM}-\mathrm{RO}_{2} \bullet$ lead to carbonyls or epoxides (Crounse et al., 2013). In addition, $\mathrm{HOM}-\mathrm{RO}_{2} \bullet$ can also be converted to alkoxy radicals (HOM-RO•) through reactions with $\mathrm{NO}$, other $\mathrm{RO}_{2} \bullet$, or $\mathrm{NO}_{3}$. If those HOM-RO• undergo an $\mathrm{H}$-migration, they will again form $\mathrm{HOM}-\mathrm{RO}_{2}$ radicals ("alkoxy-peroxy" pathway) (Mentel et al., 2015). HOM-RO• may also fragment leading to small $\mathrm{RO}_{2}$ radicals (Bianchi et al., 2019).

The clarification of $\mathrm{HOM}$-formation chemistry in limonene $+\mathrm{NO}_{3}$ system will improve the understanding of the role of HOM for SOA formation as well as the relationship between oxidation products, SOA formation and reaction systems. Donahue et al. (2012) divided atmospheric organics into five categories based on their volatility (saturation concentration, $\mathrm{C}^{*}$ ): extremely low volatility organic compounds (ELVOC), low volatility organic compounds (LVOC), semi-volatile organic compounds (SVOC), intermediate volatility organic compounds (IVOC) and volatile organic compounds (VOC). Most HOM are classified as ELVOC or LVOC (Bianchi et al., 2019), and thus HOM can be a substantial source for SOA growth through gas-particle partitioning. Field observations and laboratory simulation experiments have proven the important contribution of $\mathrm{HOM}$ in monoterpene $+\mathrm{NO}_{3} \mathrm{SOA}(\mathrm{Lee}$ et al., 2016; Faxon et al., 2018). In the SOAS campaign, HOM-ONs (organic nitrates) were identified in both gas and particle phase, including species with the sum formula $\mathrm{C}_{10} \mathrm{H}_{15,17,19} \mathrm{NO}_{4-11}$ which are formed through the oxidation of monoterpenes by $\mathrm{NO}_{3}$ (Lee et al., 2016; Massoli et al., 2018). A number of laboratory studies have reported HOM formation by the oxidation of monoterpenes with $\mathrm{NO}_{3}$. Boyd et al. (2015) observed $\mathrm{C}_{10} \mathrm{H}_{17} \mathrm{NO}_{4 / 5}$ and $\mathrm{C}_{10} \mathrm{H}_{15} \mathrm{NO}_{5 / 6}$ in the gas phase in $\beta$-pinene $+\mathrm{NO}_{3}$ experiments and proposed possible formation schemes of these ONs. Nah et al. (2016) further detected 5 and $41 \mathrm{HOM}-\mathrm{ONs}$ in the $\mathrm{NO}_{3}$ oxidation of $\alpha$-pinene and $\beta$-pinene such as $\mathrm{C}_{10} \mathrm{H}_{15 / 17 / 19} \mathrm{NO}_{4-}$ 9 in the gas- and particle-phase. Claflin and Ziemann (2018) provided formation mechanisms for HOM-ONs via gasphase and particle-phase reactions in $\beta$-pinene $+\mathrm{NO}_{3}$ experiment. Recently, Shen et al. (2021) found a large number of $\mathrm{HOM}(>150$ species $)$ in the $\beta$-pinene $+\mathrm{NO}_{3}$ reaction. Bell et al. (2021) found that dimer dinitrates $\left(\mathrm{C}_{20} \mathrm{H}_{32} \mathrm{~N}_{2} \mathrm{O}_{8-13}\right)$ contribute a large portion of SOA from $\alpha$-pinene $+\mathrm{NO}_{3}$ and also detected monomer $\mathrm{ON}$ such as $\mathrm{C}_{10} \mathrm{H}_{15} \mathrm{NO}_{5-10}$ and

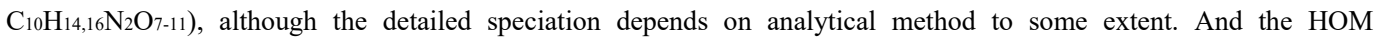


composition in the particle-phase was found to depend on aging time and conditions such as dark versus light (Bell et al., 2021; Wu et al., 2021a). Regarding the reaction of limonene with $\mathrm{NO}_{3}$, Faxon et al. (2018) reported a series of HOM in the particle phase, including $\mathrm{C}_{7-10}$ monomers with 3-11 oxygen atoms and $\mathrm{C}_{11-20}$ dimers with 5-19 oxygen atoms. However, identification of gas-phase $\mathrm{HOM}$ products in the limonene $+\mathrm{NO}_{3}$ reaction is still lacking and their formation mechanisms remain unclear.

In this study, $\mathrm{HOM}$ formation in the $\mathrm{NO}_{3}$ oxidation of limonene was investigated. We report the identification of gas-phase HOM products, including monomers, dimers and trimers. The formation pathways of dominant products in each category are proposed based on their time profiles in response of multiple additions of limonene in the experiment and on the information in literature. Based on this analysis we estimated HOM yields and discuss the role of HOM in nucleation and SOA growth.

\section{Experimental and Methods}

\subsection{Experimental setup}

The limonene $+\mathrm{NO}_{3}$ experiment was performed in the atmospheric simulation chamber SAPHIR (Simulation of Atmospheric PHotochemistry In a large Reaction chamber) at the Forschungszentrum Jülich, Germany. SAPHIR is a $270 \mathrm{~m}^{3}$ double-wall cylindrical Teflon chamber with a surface-to-volume ratio of $\sim 1 \mathrm{~m}^{2} \mathrm{~m}^{-3}$. Details of SAPHIR have been described before (Rohrer et al., 2005; Zhao et al., 2015a; Zhao et al., 2015b; Zhao et al., 2018). Detailed experimental procedures can be found in Fig. 1a. Before each experiment, SAPHIR was flushed for about $4 \mathrm{~h}$ at a flow rate of $370 \mathrm{~m}^{3} \mathrm{~h}^{-1}$ with high-purity synthetic air (purity $>99.9999 \% \mathrm{O}_{2}$ and $\mathrm{N}_{2}$ ) in order to clean the chamber. To simulate nighttime conditions for the $\mathrm{NO}_{3}$ chemistry the chamber roof remained closed throughout the experiment. The experiment was performed under dry conditions $(\mathrm{RH}<2 \%)$ at a temperature of $302 \pm 3 \mathrm{~K}$. No seed aerosols were used in the experiments.

$\mathrm{NO}_{3}$ radicals were generated via the reaction of ozone with nitrogen dioxide:

$$
\begin{aligned}
& \mathrm{NO}_{2}+\mathrm{O}_{3} \rightarrow \mathrm{NO}_{3}+\mathrm{O}_{2} \\
& \mathrm{NO}_{2}+\mathrm{NO}_{3} \leftrightarrow \mathrm{N}_{2} \mathrm{O}_{5}
\end{aligned}
$$

Therefore, $\mathrm{O}_{3}$ and $\mathrm{NO}_{2}$ were first added to the chamber to form $\mathrm{N}_{2} \mathrm{O}_{5}$ and $\mathrm{NO}_{3}$ with mixing ratios of $\sim 2$ ppbv and $\sim 0.15 \mathrm{ppbv}$, respectively. About $20 \mathrm{~min}$ later, $6 \mathrm{ppbv}$ of limonene was added to start the organic chemistry. Five more additions of limonene followed with concentrations of about 4 ppbv, 4 ppbv, 3 ppbv, 3 ppbv, and finally 10 ppbv (Fig. 1a), which divided the experiment into six periods ( $\mathrm{P} 1$ to $\mathrm{P} 6$ ). For period $\mathrm{P} 3$ and $\mathrm{P} 5, \mathrm{NO}_{2}$ and $\mathrm{O}_{3}$ were also added to compensate for the loss of $\mathrm{NO}_{3}$ and $\mathrm{N}_{2} \mathrm{O}_{5}$ (Fig. 1a). The concentrations of $\mathrm{NO}_{2}$ and $\mathrm{O}_{3}$ were maintained 
around 20 to $70 \mathrm{ppbv}$ throughout the experiment ensuring a major loss of limonene by reaction with $\mathrm{NO}_{3}$ rather than with $\mathrm{O}_{3}$ (Fig. $\mathrm{S} 1$ in the SI). In the first ten min of reaction (named period P1a hereafter), $\mathrm{NO}_{3}$ accounted for $86 \%$ of the chemical loss of limonene.

\subsection{Instrumentation}

Gas-phase HOM were detected by a Chemical Ionization time-of-flight Mass Spectrometer (CI-APi-TOF, Aerodyne Research Inc., USA) with a resolution $(m / z) /(\Delta m / z)$ of $\sim 3800$ using ${ }^{15} \mathrm{NO}_{3}{ }^{-}$as the reagent ion, which is capable of detecting organic molecules with high oxygen content (Eisele and Tanner, 1993; Jokinen et al., 2012). The mass spectra were analyzed using the software Tofware (Tofwerk/Aerodyne) in Igor Pro (WaveMetrics, Inc.). Peak identification was conducted by a high-resolution analysis. We observed several peaks which were obviously products from the isoprene $+\mathrm{NO}_{3}$ reaction, such as $\mathrm{C}_{5} \mathrm{H}_{10} \mathrm{~N}_{2} \mathrm{O}_{8} \cdot{ }^{15} \mathrm{NO}_{3}{ }^{-}$at $\mathrm{m} / \mathrm{z} 289$. Such peaks were present before the limonene oxidation reaction started, suggesting that these compounds preexisted in the chamber. They were likely released from the chamber wall as residue species from an isoprene $+\mathrm{NO}_{3}$ experiment performed two days before (Zhao et al., 2021) and are not discussed as products from the limonene oxidation in our experiment. (However, we cannot exclude that they were partly generated from fragmentation in the limonene $+\mathrm{NO}_{3}$ reaction.)

A set of instruments were used to measure other gas-phase species, including VOC, $\mathrm{NO}_{\mathrm{x}}, \mathrm{O}_{3}, \mathrm{NO}_{3}$ and $\mathrm{N}_{2} \mathrm{O}_{5}$ (Shen et al., 2021). Concentrations of $\mathrm{NO}_{3}$ and $\mathrm{N}_{2} \mathrm{O}_{5}$ were measured in-situ using a home-built diode laser-based, cavity ring-down spectrometer similar to the instrument described in the work by Wagner et al. (2011). The concentrations of limonene were measured using a Proton Transfer Reaction Time-of-Flight Mass Spectrometer (PTR-TOF-MS, Ionicon Analytik, Austria). The SOA number concentration, surface concentration and size distribution were detected by an SMPS (TSI DMA3081/TSI CPC3785). Temperature and relative humidity were continuously monitored throughout the experiment.

\subsection{Determination of HOM concentration and "primary" HOM yield}

HOM concentrations were obtained from the normalized signals to the total signals of the mass spectra (nc, normalized counts) by applying a calibration coefficient (C) of $2.5 \times 10^{10}$ molecule $\mathrm{cm}^{-3} \mathrm{nc}^{-1}$. C was determined using $\mathrm{H}_{2} \mathrm{SO}_{4}$ as the charging efficiency of $\mathrm{HOM}$ and $\mathrm{H}_{2} \mathrm{SO}_{4}$ are considered to be equal (Ehn et al., 2014; Pullinen et al., 2020; Shen et al., 2021). The details of determination of the calibration coefficient are shown in the supplement S1. A mass-independent transmission efficiency was used according to our previous study, which causes an uncertainty of $14 \%$ (Pullinen et al., 2020). The concentrations of HOM were corrected for a chamber wall loss. As the HOM yield was determined during the first 3 min of the experiment, we considered the wall loss rate to be constant $\left(6 \times 10^{-}\right.$

${ }^{4} \mathrm{~s}^{-1}$ ) during this period (Zhao et al., 2018). Sensitivity analysis proved that the HOM yield in this study is not very 
sensitive to the wall loss rate and is changing by $0.24 \%$ and $-0.12 \%$ if the wall loss rate is varied by $+100 \%$ or $50 \%$.

The HOM yield was calculated as:

$$
Y=\frac{[H O M]}{[V O C]_{r}}=\frac{I(H O M) \cdot C}{\left[N_{2} O_{5}\right]_{r}}
$$
where $[H O M]$ is the concentration of HOM, $I(H O M)$ is the total signal intensity of HOM, C the calibration factor, and $[\mathrm{VOC}]_{r}$ and $\left[\mathrm{N}_{2} \mathrm{O}_{5}\right]_{r}$ stand for the concentrations of limonene and $\mathrm{N}_{2} \mathrm{O}_{5}$ reacted, respectively. We used the reacted concentration of $\mathrm{N}_{2} \mathrm{O}_{5}$ rather than the measured reacted limonene concentration as a large fraction of limonene was already reacting away during the VOC injection before it was homogeneously mixed in the chamber. During this part of the experiment, the high limonene concentration resulted in a rapid loss of $\mathrm{NO}_{3}$, such that every $\mathrm{NO}_{3}$ formed from the decomposition of $\mathrm{N}_{2} \mathrm{O}_{5}$ reacted with limonene:

$$
\mathrm{N}_{2} \mathrm{O}_{5} \rightarrow \mathrm{NO}_{2}+\mathrm{NO}_{3}
$$

$$
\text { limonene }+\mathrm{NO}_{3} \rightarrow \text { Products }
$$

The initial $\mathrm{NO}_{3}$ concentration before the limonene injection was small compared to the time-integrated loss of $\mathrm{N}_{2} \mathrm{O}_{5}$, and other $\mathrm{NO}_{3}$ loss processes were negligible right after the limonene injection, so that the observed decrease in the $\mathrm{N}_{2} \mathrm{O}_{5}$ concentration equals indeed the consumption of limonene.

The uncertainty of the HOM yield was estimated to be $-55 \% /+117 \%$ based on the combined uncertainties of the HOM-ON peak intensities ( $\sim 10 \%)$, the limonene concentration ( $15 \%)$, the transmission efficiency $(-0 \% /+14 \%)$ and the calibration factor $(-52 \% /+101 \%)$ using error propagation (Zhao et al., 2021). The first 3 min after the injection of limonene were used to calculate the HOM yield, when most of the first-generation oxidation products were produced and negligible particles were yet formed. The HOM yield thus reflects the "primary" HOM yield.

\subsection{Determination of HOM condensation on SOA}

The SOA mass from the condensation of HOM was calculated to evaluate the role of HOM for the SOA mass growth. Detailed estimation methods are described in the supplement, including the determination of particle wall loss and dilution loss rate (Sect. S2). In brief, the growth rate of SOA through HOM vapor condensation is based on the collision rate of vapor molecules with aerosols in the kinetic regime. The Fuchs-Sutugin approach is applied to describe the correction for transition from the kinetic to the diffusion regime (Fuchs and Sutugin, 1971; Ehn et al., 2014). Based on the volatility of HOM, we considered two scenarios for HOM condensation. In Scenario 1, all HOM were assumed to irreversibly condense on the surface of particles leading to particle mass growth. In Scenario 2, only the irreversible uptake of LVOC and ELVOC compounds were considered to contribute to the SOA growth while 
IVOC and SVOC were not included. The classification of ELVOC, LVOC, IVOC and SVOC was based on the work by Donahue et al. (2012). The calculation of saturation concentration $C^{*}$ (in $\mu \mathrm{g} / \mathrm{m}^{3}$ ) of each HOM was done based on their molecular compositions using two different parameterizations considering the uncertainties in estimating volatility (Wu et al., 2021b):

1. an updated version of the parametrization of Donahue et al. (2011) by Mohr et al. (2019) (Scenario 2a):

$$
\log _{10}\left(\mathrm{C}^{*}\right)=\left(25-n_{C}\right) \times 0.475-\left(n_{O}-3 n_{N}\right) \times 0.2-2 \frac{\left(n_{O}-3 n_{N}\right) n_{C}}{\left(n_{C}+n_{O}-3 n_{N}\right)} \times 0.9-n_{N} \times 2.5
$$
where $n_{C}, n_{O}, n_{N}$ and $n_{H}$ are the number of carbon, oxygen, nitrogen and hydrogen atoms of the compound, respectively.

2. a parameterization based on HOM from $\alpha$-pinene ozonolysis by Peräkylä et al. (2020) (Scenario 2b):

$$
\log _{10}\left(\mathrm{C}^{*}\right)=n_{C} \times 0.18-n_{H} \times 0.14-n_{O} \times 0.38+n_{N} \times 0.80+3.1
$$
where $n_{C}, n_{O}, n_{N}$ and $n_{H}$ are the number of carbon, oxygen, nitrogen and hydrogen atoms of the compound, respectively.

\subsection{Simulations of the $\mathrm{RO}_{2} \bullet$ loss pathway based on the Master Chemical Mechanism (MCM)}

The $\mathrm{RO}_{2} \bullet$ loss pathways were estimated based on MCM simulations (http://mcm.york.ac.uk/). The gas-phase reactions of limonene $+\mathrm{NO}_{3}$ under dark condition were simulated using iChamber, an open-source program (https://sites.google.com/view/wangsiyuan/models?authuser=0) (Wang and Pratt, 2017). The default chemistry of limonene $+\mathrm{NO}_{3}$ in the MCM was applied in this study (Saunders et al., 2003). Photolysis reactions were excluded by setting the zenith angle to $90^{\circ}$. Concentrations of $\mathrm{O}_{3}, \mathrm{NO}_{3}, \mathrm{NO}_{2}$ and $\mathrm{N}_{2} \mathrm{O}_{5}$ as well as temperature and relative humidity were constrained to the experimental data with a time resolution of $1 \mathrm{~min}$. The chamber dilution rate of $1.5 \times 10^{-5} \mathrm{~s}^{-1}$ was applied to all species. The P1 period was simulated using the above conditions and the initial concentrations of limonene were added in the model according to the experimental procedures. The sum of all 140 $\mathrm{RO}_{2}$ • in the limonene subset of MCM v3.3.1 were used in the usual way to estimate the loss rates of $\mathrm{RO}_{2}$ • bimolecular reactions. The reaction rate constants are provided in Table S3, and calculated loss rates are shown in Fig. S2.

In the early stage of each period, $\mathrm{RO}_{2} \bullet$ mainly reacted with $\mathrm{RO}_{2} \bullet$ and $\mathrm{NO}_{3}$, although in the later stage the reaction with $\mathrm{NO}_{2}$ also contributed to a significant fraction of $\mathrm{RO}_{2} \bullet$ loss (Fig. S2, showing period P1 as an example). During the period P1a when our peak assignment was based on, the $\mathrm{RO}_{2} \bullet$ loss was dominated by $\mathrm{RO}_{2} \bullet+\mathrm{RO}_{2} \bullet$ and $\mathrm{RO}_{2} \bullet+$ $\mathrm{NO}_{3}$. 


\subsection{Experiment overview and observed HOM}

After each limonene addition, the concentration of limonene rose first and then rapidly declined, while the concentrations of $\mathrm{NO}_{3}$ and $\mathrm{N}_{2} \mathrm{O}_{5}$ rapidly decreased due to the fast reaction between limonene and $\mathrm{NO}_{3}$ and gradually increased when limonene had been consumed (Fig. 1a). About 10 min after the first limonene addition, new particles were formed and quickly grew in size (Fig. 1b). Therefore, we used the first 10 min reaction time (period P1a) to identify gas-phase HOM products, and the whole experiment to examine the contribution of HOM to SOA.

During period P1, HOM were quickly formed. We identified about $280 \mathrm{HOM}$ compounds, including monomers $\left(\mathrm{C}_{7}-\mathrm{C}_{10}, \sim 280-460 \mathrm{Th}\right)$, dimers $\left(\mathrm{C}_{17}-\mathrm{C}_{20}, \sim 490-700 \mathrm{Th}\right)$, and trimers $\left(\mathrm{C}_{26}-\mathrm{C}_{30}, \sim 720-960 \mathrm{Th}\right)$ (Fig. 2a). Their detailed formulas can be found in Table S1. HOM on the horizontal lines of the Kendrick mass defect plot (O-based) (Fig. 3 and Fig S8, S12) share the same number of $\mathrm{C}, \mathrm{N}$ and $\mathrm{H}$ atoms, with the number of oxygen atoms increasing from left to right. Such HOM compounds are defined as a family. We notice that most monomer peroxy radical families are each related to two monomer closed-shell product families, with one $\mathrm{H}$ atom more or one $\mathrm{H}$ atom less, which are the expected termination products of $\mathrm{RO}_{2} \bullet+\mathrm{RO}_{2} \bullet$ reactions, or if $\mathrm{HO}_{2} \bullet$ is present, $\mathrm{RO}_{2} \bullet+\mathrm{HO}_{2} \bullet$ termination products. These three related families are defined as a series, with the same number of $\mathrm{C}$ and $\mathrm{N}$ number, such as $\mathrm{C}_{10} \mathrm{H}_{15-17} \mathrm{NO}_{6-}$ 14. In total, we identified 6 monomer series $\left(\mathrm{C}_{10} \mathrm{H}_{15-17} \mathrm{NO}_{6-14}, \mathrm{C}_{10} \mathrm{H}_{14-16} \mathrm{~N}_{2} \mathrm{O}_{9-15}, \mathrm{C}_{10} \mathrm{H}_{14-16} \mathrm{O}_{7-12}, \mathrm{C}_{9} \mathrm{H}_{13-15} \mathrm{NO}_{7-14}, \mathrm{C}_{8} \mathrm{H}_{11-}\right.$ ${ }_{13} \mathrm{NO}_{6-13}$ and $\left.\mathrm{C}_{7} \mathrm{H}_{9-11} \mathrm{NO}_{7-11}\right)$ and 1 monomer family $\left(\mathrm{C}_{10} \mathrm{H}_{17} \mathrm{~N}_{3} \mathrm{O}_{12-16}\right), 11$ dimer families $\left(\mathrm{C}_{20} \mathrm{H}_{31} \mathrm{NO}_{10-15}, \mathrm{C}_{20} \mathrm{H}_{33} \mathrm{NO}_{12-}\right.$ 16, $\mathrm{C}_{20} \mathrm{H}_{32} \mathrm{~N}_{2} \mathrm{O}_{9-20}, \mathrm{C}_{20} \mathrm{H}_{31} \mathrm{~N}_{3} \mathrm{O}_{14-20}, \mathrm{C}_{20} \mathrm{H}_{33} \mathrm{~N}_{3} \mathrm{O}_{12-20}, \mathrm{C}_{20} \mathrm{H}_{34} \mathrm{~N}_{4} \mathrm{O}_{15-20}, \mathrm{C}_{20} \mathrm{H}_{32} \mathrm{O}_{13-16}, \mathrm{C}_{19} \mathrm{H}_{29} \mathrm{NO}_{10-13}, \mathrm{C}_{19} \mathrm{H}_{31} \mathrm{NO}_{10-15}$, $\mathrm{C}_{19} \mathrm{H}_{30} \mathrm{~N}_{2} \mathrm{O}_{10-18}$ and $\left.\mathrm{C}_{19} \mathrm{H}_{31} \mathrm{~N}_{3} \mathrm{O}_{15-19}\right)$, and 3 trimer families $\left(\mathrm{C}_{30} \mathrm{H}_{47} \mathrm{~N}_{3} \mathrm{O}_{18-24}, \mathrm{C}_{30} \mathrm{H}_{48} \mathrm{~N}_{4} \mathrm{O}_{16-24}\right.$ and $\left.\mathrm{C}_{29} \mathrm{H}_{46} \mathrm{~N}_{4} \mathrm{O}_{19-24}\right)$. Compounds containing at least one nitrogen atom accounted for more than $90 \%$ of the identified HOM products while the remaining fraction were non-nitrated products. We assume that compounds containing nitrogen atoms are organic nitrates, because other $\mathrm{N}$-containing species such as amines or nitro compounds are very unlikely formed from the reaction of limonene with $\mathrm{NO}_{3}$. Organic nitrates formed in this study could be alkylnitrates or peroxynitrates via the reaction of $\mathrm{RO}_{2} \bullet$ with $\mathrm{NO}_{2}$.

During period $\mathrm{P} 1 \mathrm{a}$, in the absence of particles, both HOM monomers and oligomers were observed, including monomers $(47 \%)$, dimers $(47 \%)$ and trimers $(6 \%)$ (Fig. 2a). Concentrations of gas-phase dimers and trimers decreased evidently after particle formation (Fig. 2b, 5, 6), indicating a fast gas-particle condensation and strong tendency of oligomers to condense on particles. 
(a)

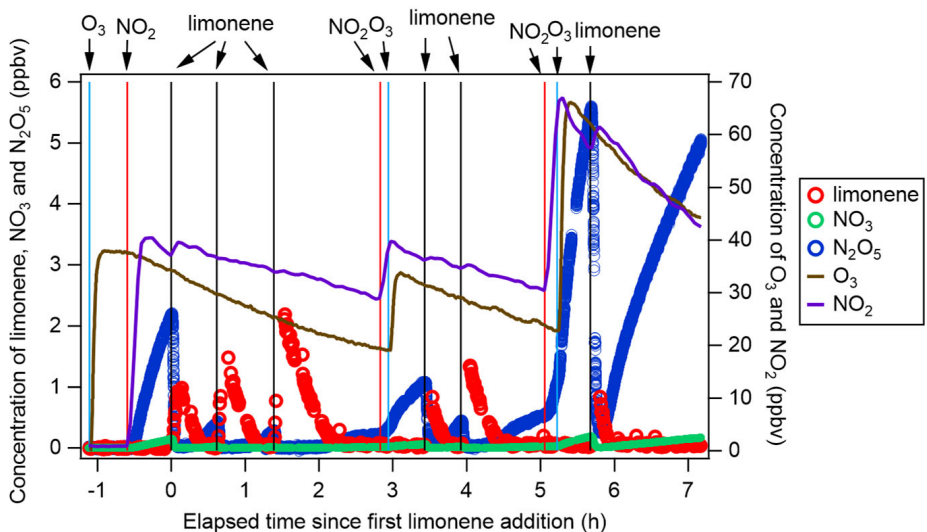

(b)

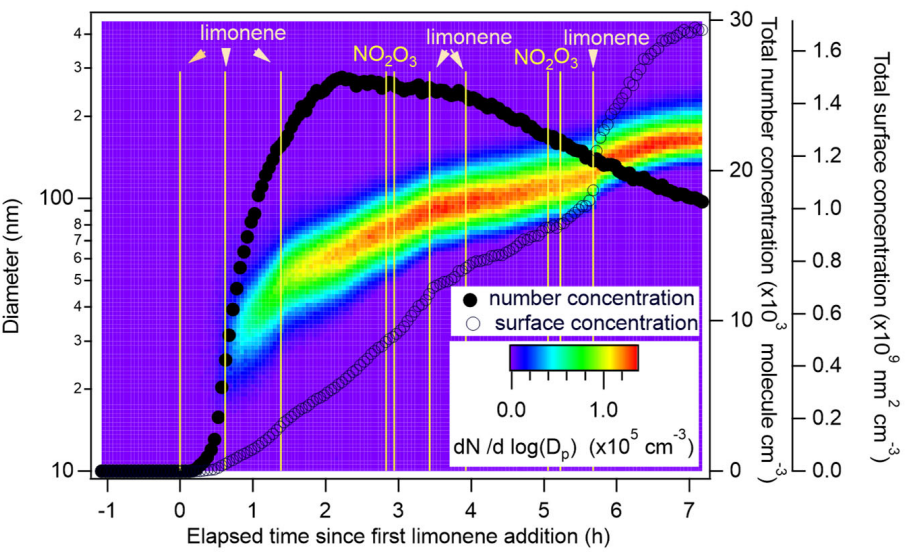

(c)

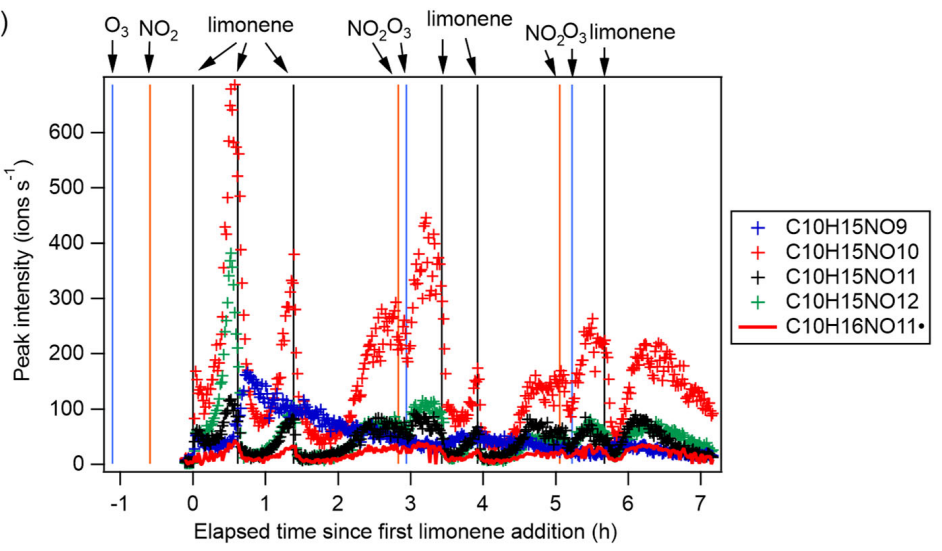

Figure 1. (a) Time series of the concentrations of limonene, $\mathrm{NO}_{3}, \mathrm{~N}_{2} \mathrm{O}_{5}$ (left panel), as well as $\mathrm{O}_{3}$ and $\mathrm{NO}_{2}$ (right panel). (b) Total particle concentration and its size distribution during the whole period of experiment detected by SMPS. The solid and hollow black circles refer to total number concentration and total surface concentration, 
intensity of typical products of the $\mathrm{C}_{10} \mathrm{H}_{15} \mathrm{NO}_{\mathrm{x}}$ family and $\mathrm{C}_{10} \mathrm{H}_{16} \mathrm{NO}_{11} \bullet$ as a representative of the $\mathrm{C}_{10} \mathrm{H}_{16} \mathrm{NO}_{\mathrm{x}}$ • family. Vertical lines indicate the time of $\mathrm{O}_{3}$ and $\mathrm{NO}_{2}$ addition, as well as six limonene injections.

Based on their typical time series, products can be classified as first-generation or second-generation products (Fig. 1c). Generally, the concentrations of first-generation products, which result from the direct reaction of limonene with $\mathrm{NO}_{3}$, are expected to quickly increase after the limonene addition, followed by a steady decline due to wall loss or chemical reactions. Concentrations of typical second-generation products, which result from further reactions of first-generation products, are expected to show a gradually increasing concentration pattern after a limonene addition and reach their maximum contribution later than first-generation products. These general expectations are modified in our case, since the particle concentration increased in our experiment (Fig. 1b) and the condensational sink of HOM products became stronger over time. Thus, an increase in concentration suggests an overcome of the increasing condensational sink by increasing production with time, i.e. from second-generation pathways.

(a)

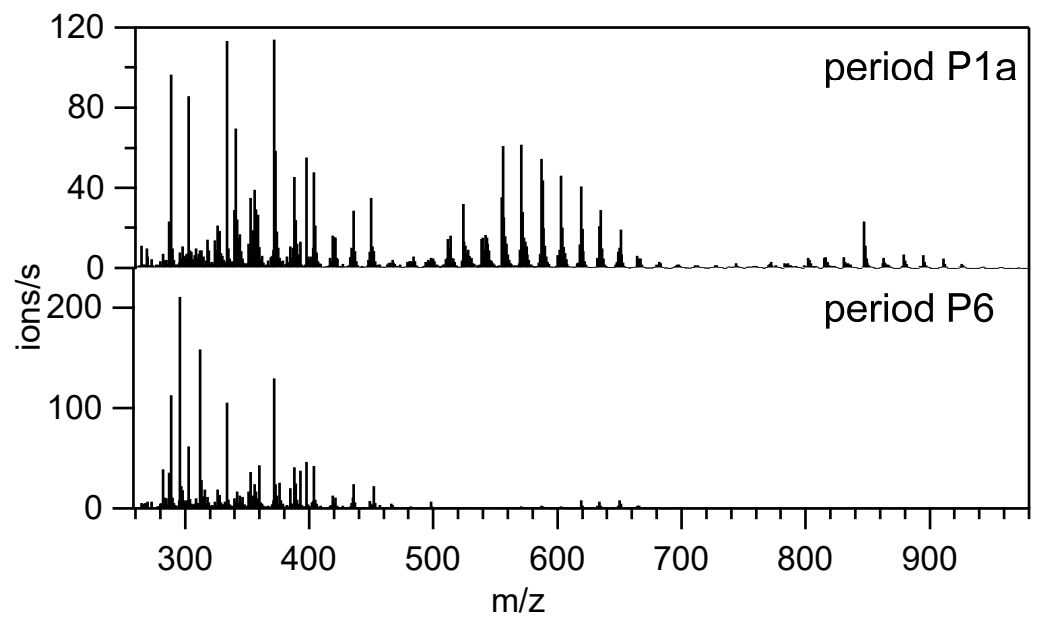

(b)
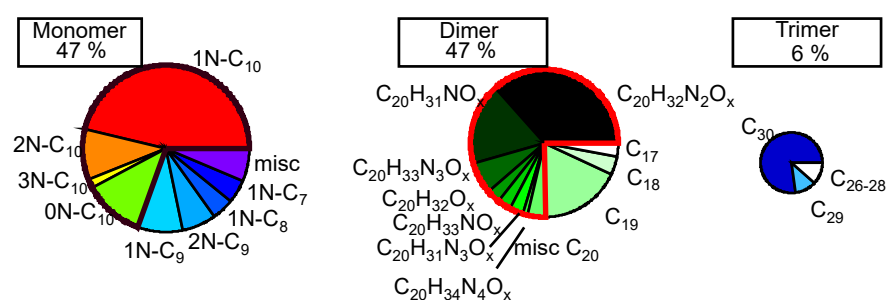

Figure 2. (a) Average mass spectra of the first 10 min reaction time after the first addition of limonene (period P1a, 
upper panel) and the last limonene addition period till particles reached maximum mass concentration (period P6, lower panel). (b) Pie charts (from left to right: rainbow, green, and blue colors) representing the relative contributions of identified series/families to HOM monomers, dimers, and trimers, respectively, during the P1a period. The area of each pie is in proportion to their concentrations during the P1a period.

\subsection{Monomers and their formation pathways}

\subsubsection{Overview of HOM monomers}

A number of HOM monomer families were detected with an increasing oxygenation pattern at 16 Th intervals (Fig. 3). During period P1a, the most abundant HOM monomers are $\mathrm{C}_{10}$ compounds (64\%), such as peroxy radicals $\mathrm{C}_{10} \mathrm{H}_{16} \mathrm{NO}_{\mathrm{x}} \cdot$ and closed-shell products $\mathrm{C}_{10} \mathrm{H}_{15} \mathrm{NO}_{x}$ and $\mathrm{C}_{10} \mathrm{H}_{17} \mathrm{NO}_{x}$, which are carbonyl compounds and hydroxyl or hydroperoxy compounds from the termination reactions of $\mathrm{C}_{10} \mathrm{H}_{16} \mathrm{NO}_{x}{ }^{\bullet}$, respectively. According to the nitrogen atoms contained, $\mathrm{C}_{10}-\mathrm{HOM}$ monomers can be classified into $1 \mathrm{~N}-, 2 \mathrm{~N}, 3 \mathrm{~N}$-monomers and monomers without nitrogen atoms. While $1 \mathrm{~N}-\mathrm{C}_{10} \mathrm{HOM}$ monomers were likely formed by direct $\mathrm{NO}_{3}$ addition to limonene, $\mathrm{C}_{10}-\mathrm{HOM}$ monomers containing multiple $\mathrm{N}$ atoms were likely formed via multiple reaction steps. Besides $\mathrm{C}_{10} \mathrm{HOM}$ monomers, $\mathrm{C}_{6-9} \mathrm{HOM}$ monomers were also observed. These $\mathrm{C}_{6-10}$ families are discussed below in the order of their contributions to HOM monomers.

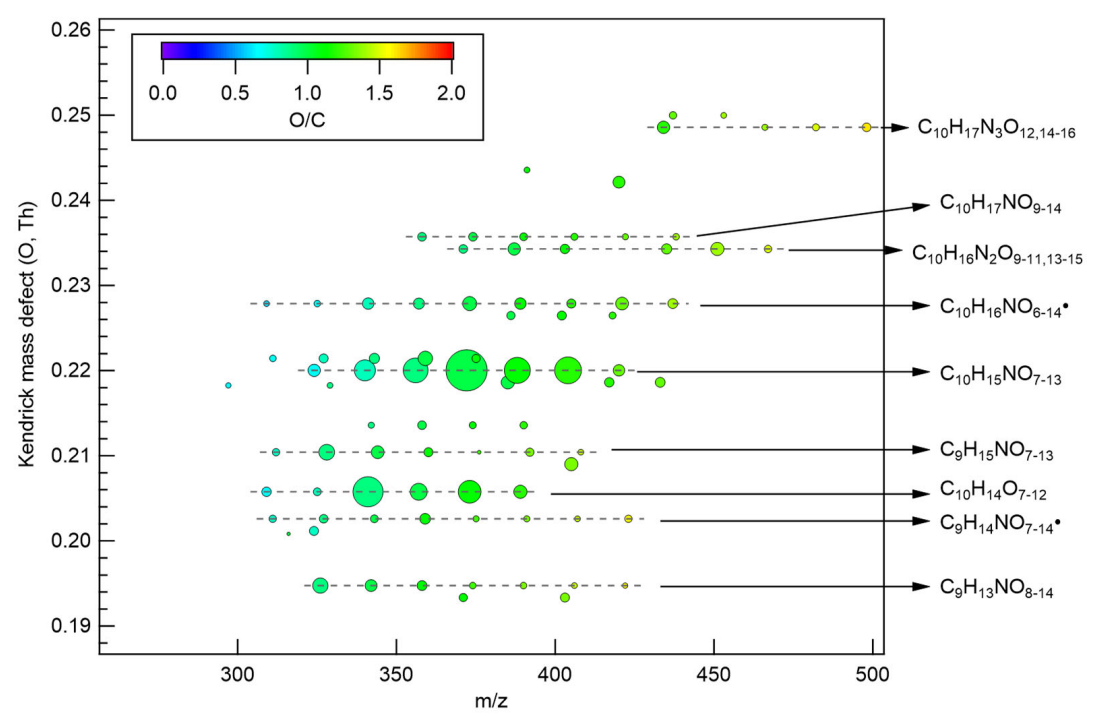

Figure 3. Kendrick mass defect plot (O-atom-based) of major monomer products. The area of the circles is proportional to the average intensity of each compound during the P1a period with the largest circle representing 
$\mathrm{C}_{10} \mathrm{H}_{15} \mathrm{NO}_{10}$. The color denotes $\mathrm{O} / \mathrm{C}$ ratios. Dashed lines indicate major product families. For clarity, the reagent ions ${ }^{15} \mathrm{NO}_{3}{ }^{-}$is omitted from molecular formula.

\subsection{2 $1 \mathrm{~N}-\mathrm{C}_{10}$ monomers}

Among $\mathrm{C}_{10} \mathrm{HOM}$ monomers, the $1 \mathrm{~N}-\mathrm{C}_{10}$ families were most abundant and included stable closed-shell products $\mathrm{C}_{10} \mathrm{H}_{15} \mathrm{NO}_{x}(\mathrm{x}=7-13)$ and $\mathrm{C}_{10} \mathrm{H}_{17} \mathrm{NO}_{\mathrm{x}}(\mathrm{x}=9-14)$ and peroxy radicals $\mathrm{C}_{10} \mathrm{H}_{16} \mathrm{NO}_{\mathrm{x}} \bullet(\mathrm{x}=6-14)$. The concentration of $\mathrm{C}_{10} \mathrm{H}_{16} \mathrm{NO}_{11} \bullet$ increased in the later phase of each limonene addition period (Fig. 1c), showing mostly a time profile of a second-generation product, similar as most of the other radicals in the $\mathrm{C}_{10} \mathrm{H}_{16} \mathrm{NO}_{\mathrm{x}} \bullet$ family (Fig. S3). However, the time series of $\mathrm{C}_{10} \mathrm{H}_{15} \mathrm{NO}_{\mathrm{x}}$ compounds showed an overlaying pattern of first- and second-generation products dominated by a second-generation time profile with the exception of $\mathrm{C}_{10} \mathrm{H}_{15} \mathrm{NO}_{9}$ (Fig. 1c). Given that $\mathrm{RO}_{2} \bullet$ are chemically active, it is likely that $\mathrm{C}_{10} \mathrm{H}_{16} \mathrm{NO}_{\mathrm{x}} \bullet$ radicals converted immediately after their formation, so that their concentrations did not exhibit a first-generation time profile. At this time, we do not have a reasonable explanation for the trend of $\mathrm{C}_{10} \mathrm{H}_{15} \mathrm{NO}_{9}$.

Since the $\mathrm{C}_{10} \mathrm{H}_{15} \mathrm{NO}_{\mathrm{x}}$ family showed an overlaying pattern of the first-generation and second-generation products, they likely contained multiple isobaric substances produced through different pathways. Based on the literature, possible formation pathways of these products were tentatively proposed (Seinfeld and Pandis, 2006; Vereecken and Peeters, 2010; Mentel et al., 2015; Vereecken and Nozière, 2020). As an example of the pathways to form first-generation products, $\mathrm{C}_{10} \mathrm{H}_{16} \mathrm{NO}_{2 \mathrm{x}-1}$ (with an odd number of oxygen atom) and their corresponding termination products can be formed via autoxidation of the first peroxy radical $\mathrm{C}_{10} \mathrm{H}_{16} \mathrm{NO}_{5} \bullet$ (R1OO), showing $\mathrm{C}_{10} \mathrm{H}_{16} \mathrm{NO}_{9} \bullet(\mathrm{R} 3 \mathrm{OO})$ as an example (Scheme 1a, first-generation products). $\mathrm{C}_{10} \mathrm{H}_{16} \mathrm{NO}_{2 \mathrm{x}} \bullet$ (with an even number of oxygen atom) can be formed via alkoxy-peroxy channels. For example, the ring-opening of the alkoxy radical $\mathrm{C}_{10} \mathrm{H}_{16} \mathrm{NO}_{4} \bullet(\mathrm{R} 1 \mathrm{O})$, which was formed via the reaction of $\mathrm{C}_{10} \mathrm{H}_{16} \mathrm{NO}_{5} \bullet$ (R1OO) with another $\mathrm{RO}_{2}$ radical or $\mathrm{NO}_{3}$ (Scheme 1a, first-generation products). Ring-opening of R1O lead to $\mathrm{C}_{10} \mathrm{H}_{16} \mathrm{NO}_{6} \bullet$ (R4OO), which can undergo autoxidation forming $\mathrm{C}_{10} \mathrm{H}_{16} \mathrm{NO}_{2 x^{\bullet}}$. In addition, the alkoxy radical $\mathrm{C}_{10} \mathrm{H}_{16} \mathrm{NO}_{4} \bullet(\mathrm{R} 1 \mathrm{O})$ is susceptible to ring-opening reactions (Novelli et al., 2021), which can lead to a first-generation stable product 3-isopropenyl-6-oxoheptanal (endolim, TP1) after C-C bond cleavage followed by the elimination of a $\mathrm{NO}_{2}$ fragment (Scheme $1 \mathrm{~b}$, secondgeneration products). Endolim (TP1) has been detected as a major product in previous limonene $+\mathrm{NO}_{3}$ studies (Hallquist et al., 1999; Spittler et al., 2006).

As an example of second-generation chemistry, the remaining double bond of endolim could react with $\mathrm{NO}_{3}$ to form $\mathrm{RO}_{2} \bullet$, followed by the autoxidation to form second-generation $\mathrm{C}_{10} \mathrm{H}_{16} \mathrm{NO}_{\mathrm{x}} \bullet$ (with odd number of oxygen atoms). 
Similar to first-generation pathways, second-generation $\mathrm{C}_{10} \mathrm{H}_{16} \mathrm{NO}_{x} \bullet$ with even number of oxygen atoms can be formed via alkoxy-peroxy channel. From the time profile of $\mathrm{C}_{10} \mathrm{H}_{15} \mathrm{NO}_{\mathrm{x}}$, the second-generation pathway (Scheme 1b) was expected to play a more important role, in agreement with the theoretical result by Kurtén et al. (2017), in which the two bond-cleavage pathways of limonene-derived RO radical were considered. It is worth mentioning that the reaction products of limonene with $\mathrm{O}_{3}$ may also react with $\mathrm{NO}_{3}$, forming $\mathrm{C}_{10} \mathrm{H}_{16} \mathrm{NO}_{\mathrm{x}} \bullet$ (Scheme $\mathrm{S} 1$ ). However, as shown above, this was a minor pathway in our experiment (Sect. 2.1). We would like to note that to simplify the scheme, only the reaction of $\mathrm{NO}_{3}$ with the endocyclic double bond is presented, since this reaction is faster than that with the exocyclic double bond (Jiang et al., 2009; Fry et al., 2011).

$\mathrm{C}_{10} \mathrm{H}_{16} \mathrm{NO}_{\mathrm{x}} \cdot$ with both even and odd number of oxygen atoms as well as their termination products had comparable abundance, which suggests that the alkoxy-peroxy pathway was important for $\mathrm{RO}_{2}$ - formation in this reaction. This finding is analogous to the findings in the reaction of a number of alkenes with $\mathrm{O}_{3}$ and in the reaction of isoprene and $\beta$-pinene with $\mathrm{NO}_{3}$ (Mentel et al., 2015; Zhao et al., 2021; Shen et al., 2021).
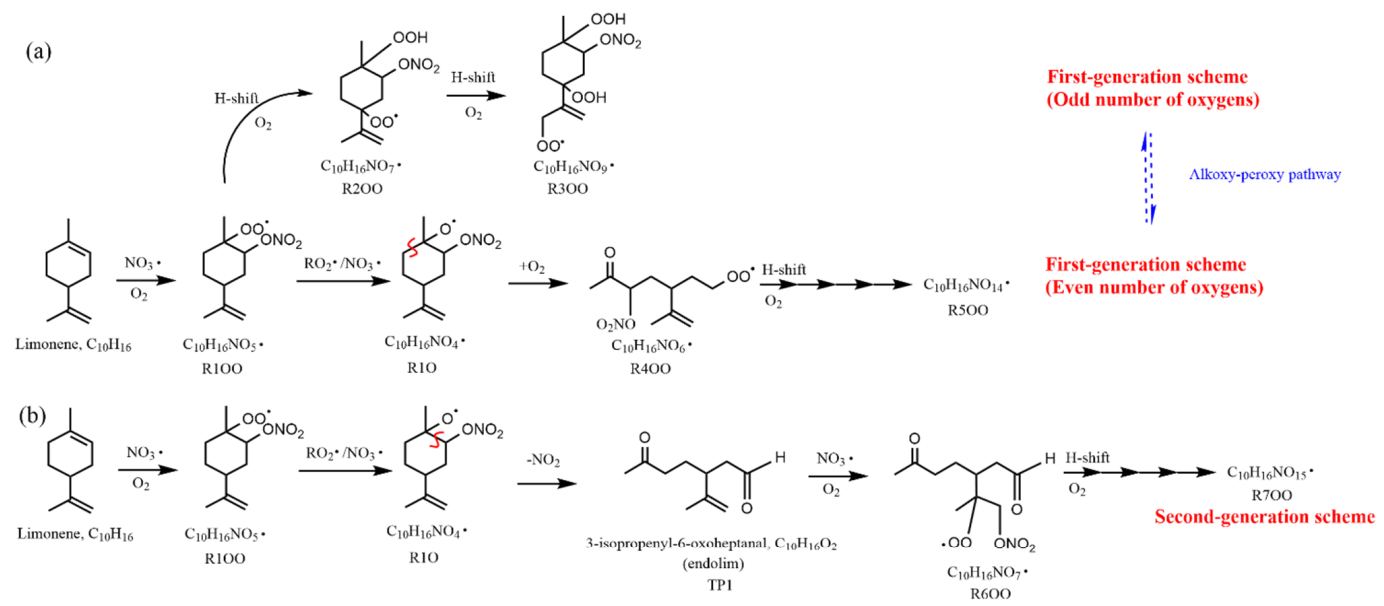

(c)

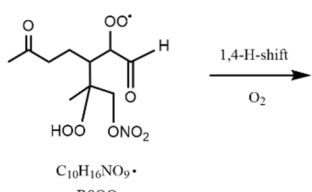<smiles>CC(=O)CCC(C(O)C(=O)O[Na])C(C)(O)CO</smiles>

R900

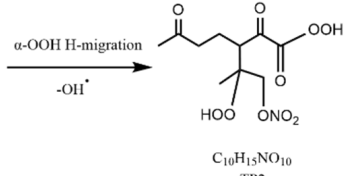

TP2

Scheme 1. Illustrative scheme for $\mathrm{HOM}$ formation in the limonene $+\mathrm{NO}_{3}$ reaction. (a) Example formation pathways leading to first-generation $1 \mathrm{~N}-\mathrm{C}_{10} \mathrm{HOM}-\mathrm{RO}_{2}$ radicals $\left(\mathrm{C}_{10} \mathrm{H}_{16} \mathrm{NO}_{\mathrm{x}} \cdot\right.$ with even or odd numbers of O-atoms). (b) Second-generation scheme involving the formation of endolim. (c) Scheme of intramolecular termination of $\mathrm{RO}_{2} \bullet$ radicals forming carbonyl products taking the $\mathrm{C}_{10} \mathrm{H}_{16} \mathrm{NO}_{9} \bullet$ radical as an example. Note that the depicted reactions 
may not be the dominant pathways.

Among $1 \mathrm{~N}-\mathrm{C}_{10}$ monomers, concentrations of carbonyl compounds were much higher than the sum of hydroxyand hydroperoxy-substituted compounds (Table 1). This finding is likely attributed to unimolecular termination reactions of $\mathrm{RO}_{2} \bullet$. The importance of unimolecular termination reactions of $\mathrm{HOM}-\mathrm{RO}_{2} \bullet$ and the resulting high ratio of carbonyl compounds to hydroxyl/hydroperoxyl compounds has also been found in the reaction system of $\beta$-pinene $+\mathrm{NO}_{3}$ (Shen et al., 2021). This high ratio is also consistent with findings in the ozonolysis of alkenes (Mentel et al., 2015), where unimolecular termination reactions were also proposed to be the likely explanation (Crounse et al., 2013; Rissanen et al., 2014). Our result thus further emphasizes that unimolecular termination reactions of $\mathrm{RO}_{2}$ radicals are important pathways in the formation of HOM monomers derived from the reactions of monoterpenes with $\mathrm{NO}_{3}$ (Shen et al., 2021). Scheme 1c shows this intramolecular termination process using a $\mathrm{C}_{10} \mathrm{H}_{16} \mathrm{NO}_{9} \bullet$ radical as an example. $\mathrm{C}_{10} \mathrm{H}_{16} \mathrm{NO}_{9} \bullet$ undergoes a 1,4-H-shift and $\mathrm{O}_{2}$ addition to form a $\mathrm{C}_{10} \mathrm{H}_{16} \mathrm{NO}_{11} \bullet$ radical. The $\mathrm{C}_{10} \mathrm{H}_{16} \mathrm{NO}_{11} \bullet$ radical further undergoes an $\mathrm{H}$-shift of the $\alpha$-OOH $\mathrm{H}$-atom, which produces a carbonyl closed-shell product as well as an $\mathrm{OH} \bullet$ radical. studies (Takeuchi and $\mathrm{Ng}, 2019$ ).

Table 1. Observed $\mathrm{C}_{10} \mathrm{H}_{16} \mathrm{NO}_{\mathrm{x}} \cdot$ radicals (m) and their termination products, including carbonyl compounds (m-17), hydroxyl compounds (m-15), and hydroperoxy compounds $(\mathrm{m}+1)$. Their concentrations during period P1a are normalized to that of $\mathrm{C}_{10} \mathrm{H}_{15} \mathrm{NO}_{10}$, which had the highest concentration among the family series of $1 \mathrm{~N}-\mathrm{C}_{10}$ monomers. Their relative intensities during the P1a period are shown in the second line of each cell.

\begin{tabular}{cccc}
\hline $\begin{array}{c}\text { Peroxy radical } \\
\mathbf{m}\end{array}$ & $\begin{array}{c}\text { Carbonyl } \\
\mathbf{m}-17\end{array}$ & $\begin{array}{c}\text { Hydroxy } \\
\mathbf{m}-15\end{array}$ & $\begin{array}{c}\text { Hydroperoxy } \\
\mathbf{m}+\mathbf{1}\end{array}$ \\
\hline $\mathrm{C}_{10} \mathrm{H}_{16} \mathrm{NO}_{6}{ }^{\bullet}$ & & & \\
$1.5 \%$ & & & \\
\hline
\end{tabular}




\begin{tabular}{cccc}
\hline $\mathrm{C}_{10} \mathrm{H}_{16} \mathrm{NO}_{7} \bullet$ & & \\
$2.0 \%$ & & & \\
$\mathrm{C}_{10} \mathrm{H}_{16} \mathrm{NO}_{8} \bullet$ & $\mathrm{C}_{10} \mathrm{H}_{15} \mathrm{NO}_{7}$ & \\
$6.7 \%$ & $8.0 \%$ & $\mathrm{C}_{10} \mathrm{H}_{17} \mathrm{NO}_{9}$ \\
\hline $\mathrm{C}_{10} \mathrm{H}_{16} \mathrm{NO}_{9} \bullet$ & $\mathrm{C}_{10} \mathrm{H}_{15} \mathrm{NO}_{8}$ & $3.7 \%$ \\
$6.0 \%$ & $25.2 \%$ & $\mathrm{C}_{10} \mathrm{H}_{17} \mathrm{NO}_{9}$ & $\mathrm{C}_{10} \mathrm{H}_{17} \mathrm{NO}_{10}$ \\
\hline $\mathrm{C}_{10} \mathrm{H}_{16} \mathrm{NO}_{10} \bullet$ & $\mathrm{C}_{10} \mathrm{H}_{15} \mathrm{NO}_{9}$ & $3.7 \%$ & $3.6 \%$ \\
$10.2 \%$ & $34.6 \%$ & $\mathrm{C}_{10} \mathrm{H}_{17} \mathrm{NO}_{10}$ & $\mathrm{C}_{10} \mathrm{H}_{17} \mathrm{NO}_{11}$ \\
\hline $\mathrm{C}_{10} \mathrm{H}_{16} \mathrm{NO}_{11} \bullet$ & $\mathrm{C}_{10} \mathrm{H}_{15} \mathrm{NO}_{10}$ & $3.6 \%$ & $3.0 \%$ \\
\hline $6.6 \%$ & $100.0 \%$ & $\mathrm{C}_{10} \mathrm{H}_{17} \mathrm{NO}_{11}$ & $\mathrm{C}_{10} \mathrm{H}_{17} \mathrm{NO}_{12}$ \\
\hline $\mathrm{C}_{10} \mathrm{H}_{16} \mathrm{NO}_{12} \bullet$ & $\mathrm{C}_{10} \mathrm{H}_{15} \mathrm{NO}_{11}$ & $3.0 \%$ & $2.3 \%$ \\
$4.1 \%$ & $39.0 \%$ & $\mathrm{C}_{10} \mathrm{H}_{17} \mathrm{NO}_{12}$ & $\mathrm{C}_{10} \mathrm{H}_{17} \mathrm{NO}_{13}$ \\
\hline \multicolumn{5}{c}{$\mathrm{C}_{10} \mathrm{H}_{15} \mathrm{NO}_{12}$} & $2.3 \%$ & $1.5 \%$ \\
\hline $\mathrm{C}_{10} \mathrm{H}_{16} \mathrm{NO}_{14} \bullet$ & $41.2 \%$ & $\mathrm{C}_{10} \mathrm{H}_{17} \mathrm{NO}_{13}$ & $\mathrm{C}_{10} \mathrm{H}_{17} \mathrm{NO}_{14}$ \\
$4.7 \%$ & $\mathrm{C}_{10} \mathrm{H}_{15} \mathrm{NO}_{13}$ & $1.5 \%$ & $1.8 \%$ \\
\hline & $6.7 \%$ & $\mathrm{C}_{10} \mathrm{H}_{17} \mathrm{NO}_{14}$ & \\
\hline
\end{tabular}

\subsection{3 $2 \mathrm{~N}$ and $3 \mathrm{~N}-\mathrm{C}_{10}$ monomers}

$\mathrm{C}_{10}$ monomers with 2 and 3 nitrogen atoms accounted for $27 \%$ and $1 \%$ of HOM monomers, respectively. They were likely formed via the reaction of a second attack of $\mathrm{NO}_{3}$ to the first-generation products with the remaining double bond from limonene. The $1 \mathrm{~N}-\mathrm{C}_{10}$ closed-shell products formed via the reactions shown in Scheme 1a should contain a remaining $\mathrm{C}=\mathrm{C}$ double bond. Typical $2 \mathrm{~N}$ - and $3 \mathrm{~N}-\mathrm{HOM}$ showed a second-generation time profile (Fig. 4). For clarity, only periods $\mathrm{P} 1$ to $\mathrm{P} 3$ are shown. This time profile is consistent with the pathways with multiple $\mathrm{NO}_{3}$ attacks. Scheme 2 shows possible formation pathways of $2 \mathrm{~N}$ - and $3 \mathrm{~N}-\mathrm{C}_{10}$ monomers. $2 \mathrm{~N}-\mathrm{C}_{10} \mathrm{HOM}$ were likely to be formed from $\mathrm{NO}_{3}$ oxidation of $1 \mathrm{~N}-\mathrm{C}_{10}$ monomers $\left(\mathrm{C}_{10} \mathrm{H}_{15} \mathrm{NO}_{\mathrm{x}}\right.$ and $\left.\mathrm{C}_{10} \mathrm{H}_{17} \mathrm{NO}_{\mathrm{x}}\right)$, resulting in $\mathrm{C}_{10} \mathrm{H}_{15} \mathrm{~N}_{2} \mathrm{O}_{\mathrm{x}} \bullet$ and $\mathrm{C}_{10} \mathrm{H}_{17} \mathrm{~N}_{2} \mathrm{O}_{\mathrm{x}} \bullet$ (Scheme 2a, 2b). While $\mathrm{C}_{10} \mathrm{H}_{15} \mathrm{~N}_{2} \mathrm{O}_{\mathrm{x}} \bullet(\mathrm{x}=9-12)$ were observed, $\mathrm{C}_{10} \mathrm{H}_{17} \mathrm{~N}_{2} \mathrm{O}_{\mathrm{x}} \bullet$ could not be uniquely identified because the peaks of the $\mathrm{C}_{10} \mathrm{H}_{17} \mathrm{~N}_{2} \mathrm{O}_{x} \cdot$ and $\mathrm{C}_{10} \mathrm{H}_{15} \mathrm{NO}_{\mathrm{x}}$ families are too close in the mass spectra to be separated based on the resolution of our mass spectrometer. $3 \mathrm{~N}-\mathrm{C}_{10}$ monomers, $\mathrm{C}_{10} \mathrm{H}_{17} \mathrm{~N}_{3} \mathrm{O}_{\mathrm{x}}$, were expected to be formed via two steps of $\mathrm{NO}_{3}$ oxidation to the double bonds and an addition of $\mathrm{NO}_{2}$ to $\mathrm{RO}_{2}$ radical, leading to a peroxynitrate or peroxyacylnitrate. $\mathrm{NO}_{2}$ addition reactions may also contribute to the formation of $2 \mathrm{~N}-\mathrm{C}_{10}$ monomers. The addition of $\mathrm{NO}_{2}$ to $\mathrm{RO}_{2}$ radicals could occur either before (Scheme 2d) or after (Scheme 2c) the second $\mathrm{NO}_{3}$ attack. 
401

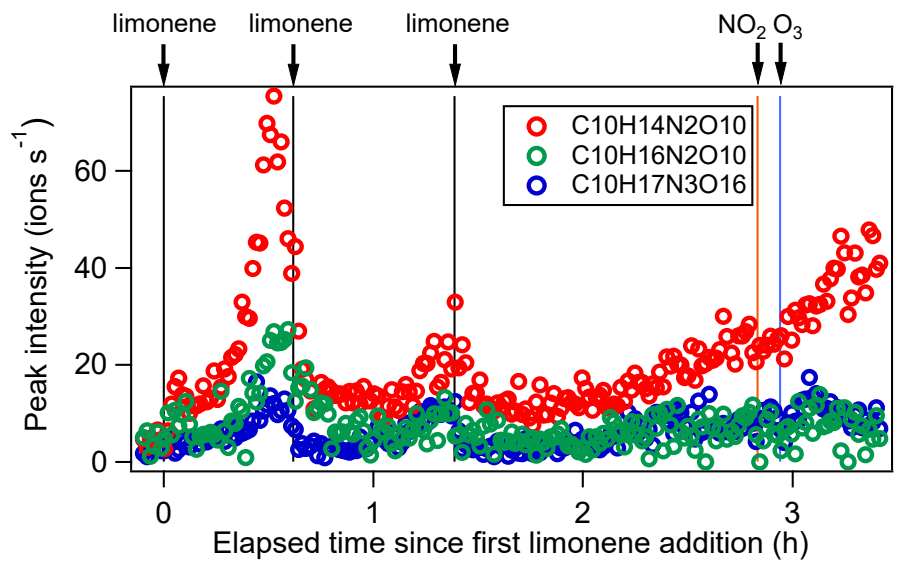

Figure 4. Time series of peak intensity of several monomers $\mathrm{C}_{10} \mathrm{H}_{14} \mathrm{~N}_{2} \mathrm{O}_{10}, \mathrm{C}_{10} \mathrm{H}_{16} \mathrm{~N}_{2} \mathrm{O}_{10}$ and $\mathrm{C}_{10} \mathrm{H}_{17} \mathrm{~N}_{3} \mathrm{O}_{16}$ as the representatives of multiple $\mathrm{N}$ monomers during the periods $\mathrm{P} 1-\mathrm{P} 3$
(a) $\mathrm{C}_{10} \mathrm{H}_{15} \mathrm{NO}_{\mathrm{n}}$
$\frac{\mathrm{NO}_{3} \cdot,+\mathrm{O}_{2}}{\mathrm{H} \text {-shift, }+\mathrm{O}_{2}}$
$\mathrm{C}_{10} \mathrm{H}_{15} \mathrm{~N}_{2} \mathrm{O}_{n+7}$
termination
$\mathrm{C}_{10} \mathrm{H}_{14} \mathrm{~N}_{2} \mathrm{O}_{\mathrm{n}+6}$
(b) $\mathrm{C}_{10} \mathrm{H}_{17} \mathrm{NO}_{\mathrm{n}}$
$\frac{\mathrm{NO}_{3} \cdot,+\mathrm{O}_{2}}{\mathrm{H} \text {-shift, }+\mathrm{O}_{2}}$
$\mathrm{C}_{10} \mathrm{H}_{17} \mathrm{~N}_{2} \mathrm{O}_{\mathrm{n}+7} \stackrel{\text { termination }}{\longrightarrow} \underset{\text { or } \mathrm{C}_{10} \mathrm{H}_{18} \mathrm{C}_{18} \mathrm{~N}_{2} \mathrm{O}_{n+6 / n+7} \mathrm{~N}_{2} \mathrm{O}_{n+6}}{\text { or }}$
(c) $\mathrm{C}_{10} \mathrm{H}_{17} \mathrm{NO}_{\mathrm{n}}$
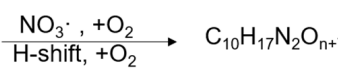
$\mathrm{NO}_{2}$ $\rightarrow \mathrm{C}_{10} \mathrm{H}_{17} \mathrm{~N}_{3} \mathrm{O}_{\mathrm{n}+9}$
(d) $\mathrm{C}_{10} \mathrm{H}_{16} \mathrm{NO}_{\mathrm{n}}$

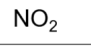
$\mathrm{C}_{10} \mathrm{H}_{16} \mathrm{~N}_{2} \mathrm{O}_{\mathrm{n}+2} \frac{\mathrm{NO}_{3} \cdot,+\mathrm{O}_{2}}{\mathrm{H}-\mathrm{shift},+\mathrm{O}_{2}}$
$\mathrm{C}_{10} \mathrm{H}_{16} \mathrm{~N}_{3} \mathrm{O}_{\mathrm{n}+9} \cdot$ termination
$\mathrm{C}_{10} \mathrm{H}_{15} \mathrm{~N}_{3} \mathrm{O}_{\mathrm{n}+8}$ or $\mathrm{C}_{10} \mathrm{H}_{17} \mathrm{~N}_{3} \mathrm{O}_{\mathrm{n}+8 / n+9}$

Scheme 2. Possible formation pathways of $\mathrm{C}_{10}$-monomers containing 2 nitrogen atoms $(\mathrm{a}, \mathrm{b})$ and 3 nitrogen atoms (c, d). Termination denotes reactions of $\mathrm{RO}_{2} \bullet$ with other $\mathrm{RO}_{2} \bullet$ or $\mathrm{HO}_{2}^{\bullet}$, or unimolecular reactions, leading to closedshell products.

\subsubsection{Formation pathways of $\mathrm{C}_{10}$ monomers without $\mathrm{N}$-atoms and monomers with less than $10 \mathrm{C}$-atoms}

Besides $\mathrm{C}_{10}$ products containing nitrogen atoms, HOM monomers without nitrogen atoms were also identified. Among these products, $\mathrm{C}_{10} \mathrm{H}_{14} \mathrm{O}_{x}(\mathrm{x}=7-12)$ were the most prevalent family, which were also detected in limonene ozonolysis (Jokinen et al., 2015). The $\mathrm{C}_{10} \mathrm{H}_{14} \mathrm{O}_{\mathrm{x}}$ family showed a time series typical of first-generation products (Fig. S4). $\mathrm{C}_{10} \mathrm{H}_{14} \mathrm{O}_{\mathrm{x}}$ and $\mathrm{C}_{10} \mathrm{H}_{16} \mathrm{O}_{\mathrm{x}}$ could be formed from limonene $+\mathrm{NO}_{3}$ with $\mathrm{C}_{10} \mathrm{H}_{16} \mathrm{NO}_{\mathrm{x}} \bullet$ terminating their autoxidation by migration of the $\alpha-\mathrm{NO}_{3} \mathrm{H}$-atom, eliminating an $\mathrm{NO}_{2}$ fragment (Scheme S2) (Novelli et al., 2021). Alternatively, these products could be formed via the reaction of $\mathrm{O}_{3}$ with limonene (Scheme $\mathrm{S} 2$ ). In either way, $\mathrm{C}_{10} \mathrm{H}_{14} \mathrm{O}_{\mathrm{x}}$ and 
We also observed monomers with carbon atom number less than 10 . During the P1a period, $\mathrm{C}_{9}$ monomer families were the most abundant contributors to $\mathrm{C}<10 \mathrm{HOM}$ monomers, followed by $\mathrm{C}_{8}$ families. The majority of $\mathrm{C}_{9}$ monomers were $\mathrm{C}_{9} \mathrm{H}_{15} \mathrm{NO}_{x}(x=7-13)$ and $\mathrm{C}_{9} \mathrm{H}_{13} \mathrm{NO}_{\mathrm{x}}(\mathrm{x}=8-14)$. The loss of one carbon atom may follow the mechanism shown in Scheme S3 (Fry et al., 2011; Bianchi et al., 2019). The major product family in $\mathrm{C}_{8}$ monomers is $\mathrm{C}_{8} \mathrm{H}_{11} \mathrm{NO}_{\mathrm{x}}(\mathrm{x}=6,7,9-13)$. While during period $\mathrm{P} 1 \mathrm{a} \mathrm{C}_{8} \mathrm{H}_{11} \mathrm{NO}_{\mathrm{x}}$ compounds could be hardly observed, their concentrations increased considerably in the later periods (Fig. S6). The gas-phase concentration of $\mathrm{C}_{8} \mathrm{H}_{11} \mathrm{NO}_{7}$ was even the highest among all compounds in later periods (highest intensity signal in Fig. 2b). This is partly attributed to the relatively high volatility of $\mathrm{C} 8$ compounds compared with $\mathrm{C} 10 \mathrm{HOM}$ species and accretion products, which tend to condense on particles. The major family in $\mathrm{C}_{7}$ monomers, $\mathrm{C}_{7} \mathrm{H}_{9} \mathrm{NO}_{\mathrm{x}}(\mathrm{x}=6-13)$, showed a time series pattern similar to $\mathrm{C}_{8} \mathrm{H}_{11} \mathrm{NO}_{\mathrm{x}}$ compounds (Fig. S7). Such a time profile indicates that $\mathrm{C}_{7}$ and $\mathrm{C}_{8}$ products were likely a result of multi-generation gas-phase reactions.

\subsection{Dimers and their formation}

Among dimers, $\mathrm{C}_{20}$ products were the most abundant, followed by $\mathrm{C}_{19}$ products. Among $\mathrm{C}_{20}$ and $\mathrm{C}_{19}$ dimers, the most prevalent families included $\mathrm{C}_{20} \mathrm{H}_{32} \mathrm{~N}_{2} \mathrm{O}_{\mathrm{x}}(\mathrm{x}=9-20), \mathrm{C}_{20} \mathrm{H}_{33} \mathrm{~N}_{3} \mathrm{O}_{\mathrm{x}}(\mathrm{x}=12-20), \mathrm{C}_{20} \mathrm{H}_{31} \mathrm{NO}_{\mathrm{x}}(\mathrm{x}=10-15), \mathrm{C}_{20} \mathrm{H}_{31} \mathrm{~N}_{3} \mathrm{O}_{\mathrm{x}}$ $(\mathrm{x}=14-20), \mathrm{C}_{20} \mathrm{H}_{34} \mathrm{~N}_{4} \mathrm{O}_{\mathrm{x}}(\mathrm{x}=15-20)$, and $\mathrm{C}_{19} \mathrm{H}_{30} \mathrm{~N}_{2} \mathrm{O}_{\mathrm{x}}(\mathrm{x}=10-18)$ (Fig. $\mathrm{S} 8$ ). The $\mathrm{O} / \mathrm{C}$ ratio of dimers did not exceed one, while that of monomers was as high as two. This could be due to oxygen atom loss and participation of less oxygenated $\mathrm{RO}_{2} \bullet$ in the dimer formation as discussed below. Time series of dimers also showed different patterns compared to monomers. For example, compounds of the $\mathrm{C}_{20} \mathrm{H}_{32} \mathrm{~N}_{2} \mathrm{O}_{\mathrm{x}}$ family only reached a considerable peak intensity in period P1 and decreased rapidly, and the signal intensity in periods P2 to P6 were low (Fig. 5). Other dimers showed similar patterns (Fig. S9-11). The time when signals of dimers dropped substantially matched the time of new particle formation (NPF) and the onset of particle growth, indicating that dimers were likely to contribute to early growth of particles. Such a behavior is expected since dimers have a much lower volatility than monomers. This observation is consistent with the laboratory study by Faxon et al. (2018) that found a significant fraction of $\mathrm{HOM}$ dimer derived from limonene $+\mathrm{NO}_{3}$ in the particle phase. 


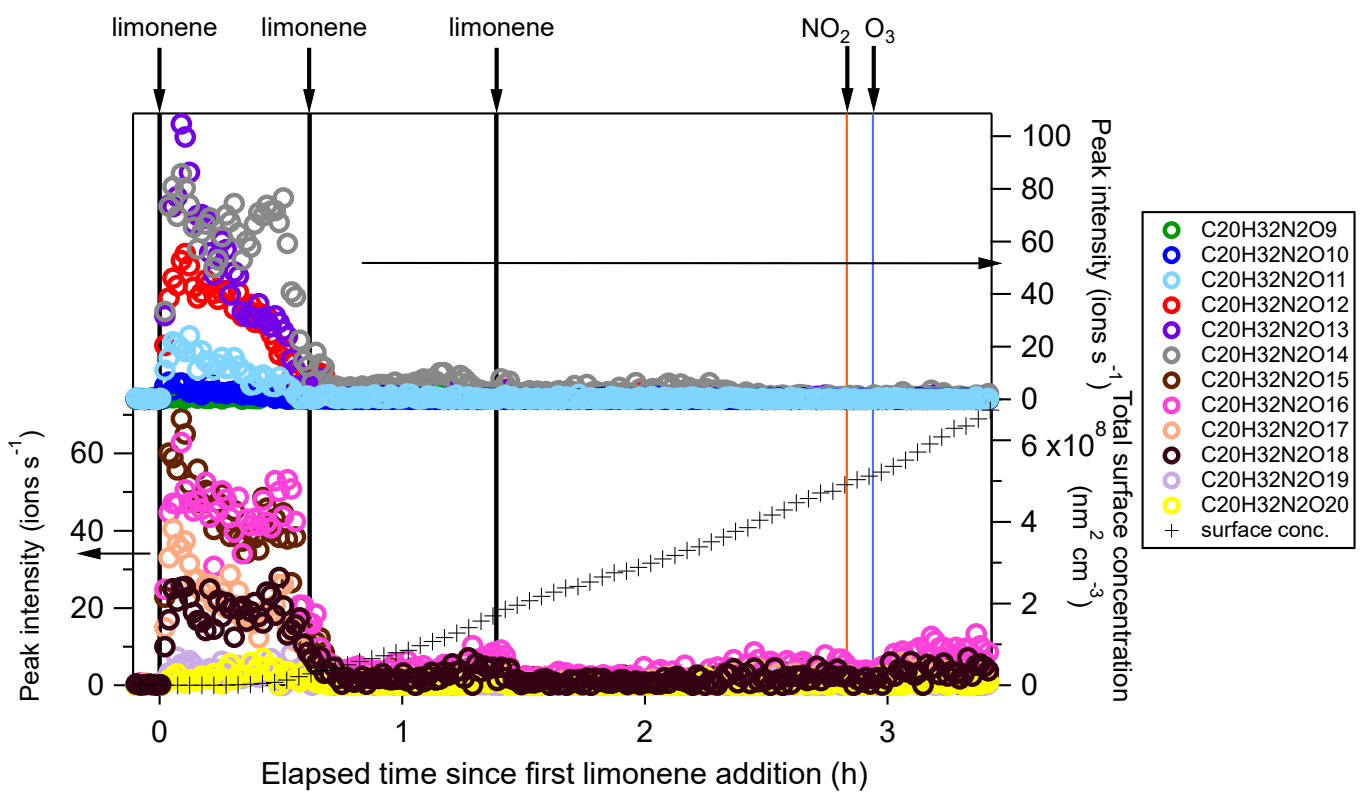

Figure 5. Time series of peak intensity of the $\mathrm{C}_{20} \mathrm{H}_{32} \mathrm{~N}_{2} \mathrm{O}_{x}$ family compounds during the periods $\mathrm{P} 1$ to $\mathrm{P} 3$. The cross markers (lower right y-axis) indicate total particle surface concentration.

In general, $\mathrm{C}_{20} \mathrm{H}_{32} \mathrm{~N}_{2} \mathrm{O}_{x}$ showed an overlaying time profile of first- and second-generation products (Fig. 5). $\mathrm{C}_{20} \mathrm{H}_{32} \mathrm{~N}_{2} \mathrm{O}_{\mathrm{x}}$ were likely formed via the accretion reaction between two monomer $\mathrm{RO}_{2} \bullet\left(\mathrm{C}_{10} \mathrm{H}_{16} \mathrm{NO}_{\mathrm{x}} \bullet\right)$ :

$$
\mathrm{C}_{10} \mathrm{H}_{16} \mathrm{NO}_{\mathrm{x} 1} \bullet+\mathrm{C}_{10} \mathrm{H}_{16} \mathrm{NO}_{\mathrm{x} 2} \bullet \mathrm{C}_{20} \mathrm{H}_{32} \mathrm{~N}_{2} \mathrm{O}_{\mathrm{x} 1+x 2-2}+\mathrm{O}_{2}
$$

Since $\mathrm{C}_{10} \mathrm{H}_{16} \mathrm{NO}_{\mathrm{x}} \cdot$ can be first- or second-generation products, the resulting dimers $\mathrm{C}_{20} \mathrm{H}_{32} \mathrm{~N}_{2} \mathrm{O}_{\mathrm{x}}$ can also be first- or second-generation products. Time series showed that $\mathrm{C}_{20} \mathrm{H}_{32} \mathrm{~N}_{2} \mathrm{O}_{x}$ with less $\mathrm{O}$ number presented more of a firstgeneration product time profile (Fig. 5). The relative contribution of second-generation formation tended to increase with oxygen number.

We compared the observed dimer formula with those expected based on accretion reactions of $\mathrm{HOM}_{-\mathrm{RO}_{2}} \cdot \mathrm{X}$ in the $\mathrm{C}_{20} \mathrm{H}_{32} \mathrm{~N}_{2} \mathrm{O}_{x}$ observed was $\geq 9$; however, according to the accretion mechanism and the observed $\mathrm{C}_{10} \mathrm{H}_{16} \mathrm{NO}_{\mathrm{x}}{ }^{\bullet}$ ( $x \geq 6$ ), $x$ in $\mathrm{C}_{20} \mathrm{H}_{32} \mathrm{~N}_{2} \mathrm{O}_{\mathrm{x}}$ should be $\geq 10(6+6-2=10)$. Moreover, as the most abundant $\mathrm{RO}_{2} \bullet$ within the $\mathrm{C}_{10} \mathrm{H}_{16} \mathrm{NO}_{\mathrm{x}} \bullet$ family was $\mathrm{C}_{10} \mathrm{H}_{16} \mathrm{NO}_{10}$ (Table 1 ), the most abundant $\mathrm{C}_{20} \mathrm{H}_{32} \mathrm{~N}_{2} \mathrm{O}_{x}$ was expected to have an oxygen number of 18 according to the accretion reaction mechanism. This contradicted the fact that the most abundant molecule among the $\mathrm{C}_{20} \mathrm{H}_{32} \mathrm{~N}_{2} \mathrm{O}_{\mathrm{x}}$ family was $\mathrm{C}_{20} \mathrm{H}_{32} \mathrm{~N}_{2} \mathrm{O}_{13}$. The findings above could only be explained by the participation of less oxygenated $\mathrm{RO}_{2} \bullet$ such as $\mathrm{C}_{10} \mathrm{H}_{16} \mathrm{NO}_{5,6} \bullet$ in the accretion reaction (Berndt et al., 2018a; Berndt et al., 2018b; Mcfiggans 
et al., 2019; Pullinen et al., 2020). $\mathrm{C}_{10} \mathrm{H}_{16} \mathrm{NO}_{5} \cdot$ was not detected in by our CI-APi-TOF, which is attributed to the lower detection sensitivity of molecules with $\mathrm{O}$ number $\leq 5$ in the $\mathrm{NO}_{3}{ }^{-}$-CIMS (Riva et al., 2019). $\mathrm{C}_{10} \mathrm{H}_{16} \mathrm{NO}_{5} \bullet$ is the first $\mathrm{RO}_{2}$ radical formed in the limonene $+\mathrm{NO}_{3}$ reaction (Scheme 1a). If we assume that the abundance of $\mathrm{C}_{10} \mathrm{H}_{16} \mathrm{NO}_{5} \bullet$ was high, and considering that the concentration of $\mathrm{C}_{10} \mathrm{H}_{16} \mathrm{NO}_{10} \bullet$ was the highest in the $\mathrm{C}_{10} \mathrm{H}_{16} \mathrm{NO}_{\mathrm{x}} \bullet$ family, their accretion reaction (R10) could form $\mathrm{C}_{20} \mathrm{H}_{32} \mathrm{~N}_{2} \mathrm{O}_{13}$ and justify that $\mathrm{C}_{20} \mathrm{H}_{32} \mathrm{~N}_{2} \mathrm{O}_{13}$ was the most abundant $\mathrm{C}_{20}$ dimer product:

$$
\mathrm{C}_{10} \mathrm{H}_{16} \mathrm{NO}_{5} \bullet+\mathrm{C}_{10} \mathrm{H}_{16} \mathrm{NO}_{10} \bullet \rightarrow \mathrm{C}_{20} \mathrm{H}_{32} \mathrm{~N}_{2} \mathrm{O}_{13}+\mathrm{O}_{2}
$$

Time series of dimers with unequal numbers of $\mathrm{N}$ atoms were different, indicating different formation pathways. For example, the $\mathrm{C}_{20} \mathrm{H}_{31} \mathrm{NO}_{x}$ family were mainly first-generation products (Fig. S9), which may be formed via the following reaction:

$$
\mathrm{C}_{10} \mathrm{H}_{16} \mathrm{NO}_{\mathrm{x} 1} \bullet+\mathrm{C}_{10} \mathrm{H}_{15} \mathrm{O}_{\mathrm{x} 2} \bullet \rightarrow \mathrm{C}_{20} \mathrm{H}_{31} \mathrm{NO}_{\mathrm{x} 1+\mathrm{x} 2-2}+\mathrm{O}_{2}
$$

$\mathrm{C}_{10} \mathrm{H}_{15} \mathrm{O}_{\mathrm{x}} \bullet$ were first-generation radicals (Sect. 3.2.4), while $\mathrm{C}_{10} \mathrm{H}_{16} \mathrm{NO}_{\mathrm{x}} \bullet$ were mainly second-generation radicals. $\mathrm{C}_{10} \mathrm{H}_{16} \mathrm{NO}_{\mathrm{x}} \bullet$ could also be formed via first-generation pathway as discussed above (Scheme 1a), but that was not apparent by the time profile, suggesting a fast termination of first-generation $\mathrm{C}_{10} \mathrm{H}_{16} \mathrm{NO}_{\mathrm{x}} \bullet$ radicals. Reaction R11 could be one of the termination pathways of first-generation $\mathrm{C}_{10} \mathrm{H}_{16} \mathrm{NO}_{\mathrm{x}} \bullet$ based on the first-generation time profile of $\mathrm{C}_{20} \mathrm{H}_{31} \mathrm{NO}_{\mathrm{x}}$. In the study by Faxon et al. (2018), the formation of $1 \mathrm{~N}-\mathrm{C}_{20}$ dimers was explained by a mechanism involving two $1 \mathrm{~N}-\mathrm{RO}_{2}$ radicals which produced $\mathrm{HNO}_{3}$ as a by-product. However, $\mathrm{C}_{10} \mathrm{RO}_{2}$ radicals without nitrogen atoms were identified in our study, which provided a direct formation pathway of $1 \mathrm{~N}-\mathrm{C}_{20}$ dimers through $\mathrm{R} 11$.

On the other hand, $\mathrm{C}_{20} \mathrm{H}_{33} \mathrm{~N}_{3} \mathrm{O}_{x}$ and $\mathrm{C}_{20} \mathrm{H}_{34} \mathrm{~N}_{4} \mathrm{O}_{x}$ were mainly second-generation products (Fig. S10, 11). $\mathrm{C}_{20} \mathrm{H}_{33} \mathrm{~N}_{3} \mathrm{O}_{\mathrm{x}}$ and $\mathrm{C}_{20} \mathrm{H}_{34} \mathrm{~N}_{4} \mathrm{O}_{\mathrm{x}}$ were likely to be formed via $\mathrm{NO}_{3}$ oxidation of dimers containing less nitrogen atoms, and were thus second-generation products. The related radicals were also detected, such as $\mathrm{C}_{20} \mathrm{H}_{32} \mathrm{~N}_{3} \mathrm{O}_{\mathrm{x}} \bullet(\mathrm{x}=16-19)$ and $\mathrm{C}_{20} \mathrm{H}_{31} \mathrm{~N}_{2} \mathrm{O}_{x} \bullet(x=13-16)$. Possible formation pathways of dominant oligomer families are displayed in Table 2.

Table 2. Major dimer and trimer families and their possible formation pathways.

\begin{tabular}{cc}
\hline Dimer/Trimer family & Possible formation pathways \\
\hline $\mathrm{C}_{20} \mathrm{H}_{32} \mathrm{~N}_{2} \mathrm{O}_{\mathrm{x}}$ & $\mathrm{C}_{10} \mathrm{H}_{16} \mathrm{NO}_{\mathrm{x}} \bullet+\mathrm{C}_{10} \mathrm{H}_{16} \mathrm{NO}_{\mathrm{x}} \bullet$ \\
$\mathrm{C}_{20} \mathrm{H}_{33} \mathrm{~N}_{3} \mathrm{O}_{\mathrm{x}} / \mathrm{C}_{20} \mathrm{H}_{31} \mathrm{~N}_{3} \mathrm{O}_{\mathrm{x}}$ & $\mathrm{C}_{20} \mathrm{H}_{32} \mathrm{~N}_{2} \mathrm{O}_{\mathrm{x}}+\mathrm{NO}_{3}+\mathrm{HO}_{2} \bullet / \mathrm{RO}_{2} \bullet$ \\
$\mathrm{C}_{20} \mathrm{H}_{31} \mathrm{NO}_{\mathrm{x}}$ & $\mathrm{C}_{10} \mathrm{H}_{16} \mathrm{NO}_{\mathrm{x}} \bullet+\mathrm{C}_{10} \mathrm{H}_{15} \mathrm{O}_{\mathrm{x}} \bullet$ \\
$\mathrm{C}_{20} \mathrm{H}_{33} \mathrm{NO}_{\mathrm{x}}$ & Unknown \\
\hline
\end{tabular}




\begin{tabular}{cc}
\hline $\mathrm{C}_{20} \mathrm{H}_{34} \mathrm{~N}_{4} \mathrm{O}_{\mathrm{x}}$ & Unknown \\
$\mathrm{C}_{19} \mathrm{H}_{30} \mathrm{~N}_{2} \mathrm{O}_{\mathrm{x}}$ & $\mathrm{C}_{10} \mathrm{H}_{16} \mathrm{NO}_{\mathrm{x}} \bullet+\mathrm{C}_{9} \mathrm{H}_{14} \mathrm{NO}_{\mathrm{x}} \bullet$ \\
$\mathrm{C}_{19} \mathrm{H}_{31} \mathrm{~N}_{3} \mathrm{O}_{\mathrm{x}}$ & $\mathrm{C}_{19} \mathrm{H}_{30} \mathrm{~N}_{2} \mathrm{O}_{\mathrm{x}}+\mathrm{NO}_{3}+\mathrm{HO}_{2} \bullet / \mathrm{RO}_{2} \bullet$ \\
$\mathrm{C}_{19} \mathrm{H}_{29} \mathrm{NO}_{\mathrm{x}}$ & $\mathrm{C}_{9} \mathrm{H}_{14} \mathrm{NO}_{\mathrm{x}} \bullet+\mathrm{C}_{10} \mathrm{H}_{15} \mathrm{O}_{\mathrm{x}} \bullet$ \\
$\mathrm{C}_{19} \mathrm{H}_{31} \mathrm{NO}_{\mathrm{x}}$ & Unknown \\
$\mathrm{C}_{30} \mathrm{H}_{48} \mathrm{~N}_{4} \mathrm{O}_{\mathrm{x}}$ & $\mathrm{C}_{20} \mathrm{H}_{32} \mathrm{~N}_{3} \mathrm{O}_{\mathrm{x}} \bullet+\mathrm{C}_{10} \mathrm{H}_{16} \mathrm{NO}_{\mathrm{x}} \bullet$ \\
$\mathrm{C}_{30} \mathrm{H}_{47} \mathrm{~N}_{3} \mathrm{O}_{\mathrm{x}}$ & $\mathrm{C}_{20} \mathrm{H}_{31} \mathrm{~N}_{2} \mathrm{O}_{\mathrm{x}} \bullet+\mathrm{C}_{10} \mathrm{H}_{16} \mathrm{NO}_{\mathbf{x}} \bullet$ \\
\hline
\end{tabular}

\subsection{Trimers and their formation}

Trimers were dominated by $\mathrm{C}_{30}$ compounds (Fig. S12). To the best of our knowledge, this is the first study that identified gas-phase trimers in the limonene $+\mathrm{NO}_{3}$ reaction. The $\mathrm{O} / \mathrm{C}$ ratio of trimers were lower than that of monomers and dimers, suggesting possible multiple accretion reactions in their formation pathways, which lose 2 oxygen atoms in each reaction. As each accretion reaction terminates peroxy radicals, the observation of trimers also implies that some dimers could further react with $\mathrm{NO}_{3}$. The most prevalent product families were $\mathrm{C}_{30} \mathrm{H}_{48} \mathrm{~N}_{4} \mathrm{O}_{\mathrm{x}}(\mathrm{x}=16-$ 24) and $\mathrm{C}_{30} \mathrm{H}_{47} \mathrm{~N}_{3} \mathrm{O}_{\mathrm{x}}(\mathrm{x}=18,19,21,23,24)$, which were likely formed via the most abundant monomer $\mathrm{RO}_{2} \bullet$ radicals $\mathrm{C}_{10} \mathrm{H}_{16} \mathrm{NO}_{\mathrm{x}} \bullet$ and the most abundant dimer $\mathrm{RO}_{2}$ radicals $-\mathrm{C}_{20} \mathrm{H}_{32} \mathrm{~N}_{3} \mathrm{O}_{\mathrm{x}} \bullet$ and $\mathrm{C}_{20} \mathrm{H}_{31} \mathrm{~N}_{2} \mathrm{O}_{\mathrm{x}} \bullet$. Trimers from other monoterpenes $+\mathrm{NO}_{3}$ have been observed in previous laboratory studies. For example, $\mathrm{C}_{30} \mathrm{H}_{48} \mathrm{~N}_{4} \mathrm{O}_{16}$ and $\mathrm{C}_{30} \mathrm{H}_{47} \mathrm{~N}_{3} \mathrm{O}_{16}$ were observed in the mass spectra of $\alpha$-pinene $+\mathrm{NO}_{3}$ SOA by Wu et al. (2021a), and $\mathrm{C}_{30} \mathrm{H}_{47} \mathrm{~N}_{3} \mathrm{O}_{13}$ was identified in $\beta$-pinene $+\mathrm{NO}_{3}$ SOA by Claflin and Ziemann (2018).

Similar to their precursors $\mathrm{C}_{20} \mathrm{H}_{32} \mathrm{~N}_{2} \mathrm{O}_{\mathrm{x}}, \mathrm{C}_{30} \mathrm{H}_{48} \mathrm{~N}_{4} \mathrm{O}_{\mathrm{x}}$ showed negligible signal except in period $\mathrm{P} 1$, and presented an overlaying time profile of first- and second-generation product pattern (Fig. 6). For comparison, gas-phase trimer products were not observed in the $\beta$-pinene $+\mathrm{NO}_{3}$ reaction (Shen et al., 2021), and the trimers observed in SOA from $\beta$-pinene $+\mathrm{NO}_{3}$ were likely formed via particle phase reactions (Claflin and Ziemann, 2018). An efficient gas-phase trimer production via subsequent accretion reactions between peroxy radicals requires that the precursor dimer has high enough reactivity to create a dimer $\mathrm{RO}_{2} \bullet$, e.g. via $\mathrm{NO}_{3}$ reaction to a double bond. This suggests that the VOC containing at least two double bonds are likely more favorable to form trimers, which is consistent with our previous findings that trimers were formed in the $\mathrm{NO}_{3}$ reaction with isoprene which also contains two double bonds (Zhao et al., 2021) while they were not observed in the reaction of $\mathrm{NO}_{3}$ with $\beta$-pinene which contains only one double bond (Shen et al., 2021). 


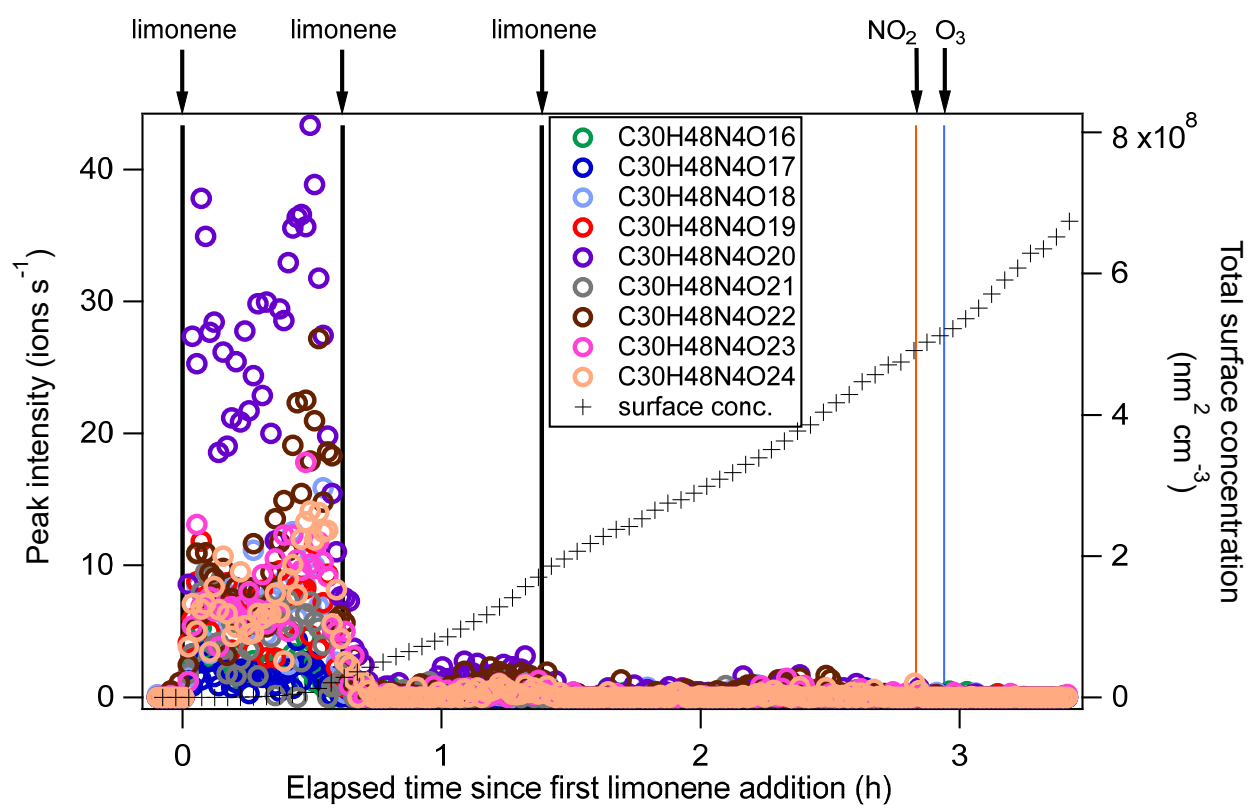

Figure 6. Time series of peak intensity of the $\mathrm{C}_{30} \mathrm{H}_{48} \mathrm{~N}_{4} \mathrm{O}_{\mathrm{x}}$ family compounds during the periods $\mathrm{P} 1$ to $\mathrm{P} 3$. The cross markers (right y-axis) indicate total particle surface concentration.

\section{5 "Primary" incremental HOM yields}

We chose period P1 for the calculation of HOM yields in order to minimize the influence of the condensational sink on HOM concentration. However, both first-generation and second-generation products existed in this period, as discussed in Sect. 3.2 through 3.4 and supported by the time-behavior of the total HOM concentration (Fig. S13). Period P1 can be roughly divided into three phases based on the trend of HOM concentration. Shortly after the limonene injection, large quantities of HOM were produced (first-production phase) followed by a steady intermediate phase when HOM concentrations stopped increasing. After the intermediate phase, HOM concentrations began to increase again (second-production phase). The first-production phase overlapped with the time span where limonene, $\mathrm{NO}_{3}$ and $\mathrm{N}_{2} \mathrm{O}_{5}$ concentrations decreased, implying the dominance of first-generation HOM production process. During the second production period, wall loss was compensated by second-generation HOM formation, leading to another rise of the total HOM concentrations. Therefore, we use the first-production phase to estimate primary HOM production, determined over the first $3 \mathrm{~min}$ of the experiment. The calculated "primary" HOM molar yield is $1.5 \%$ \% $\%_{0.7}^{+1.7 \%}$. This value is significantly lower than the HOM yield of 5 to $17 \%$ in earlier limonene ozonolysis experiments (Ehn et al., 2014; Jokinen et al., 2015; Pagonis et al., 2019). It should be noted that second-generation 


\subsection{Contribution of HOM to particle formation and growth}

(a)
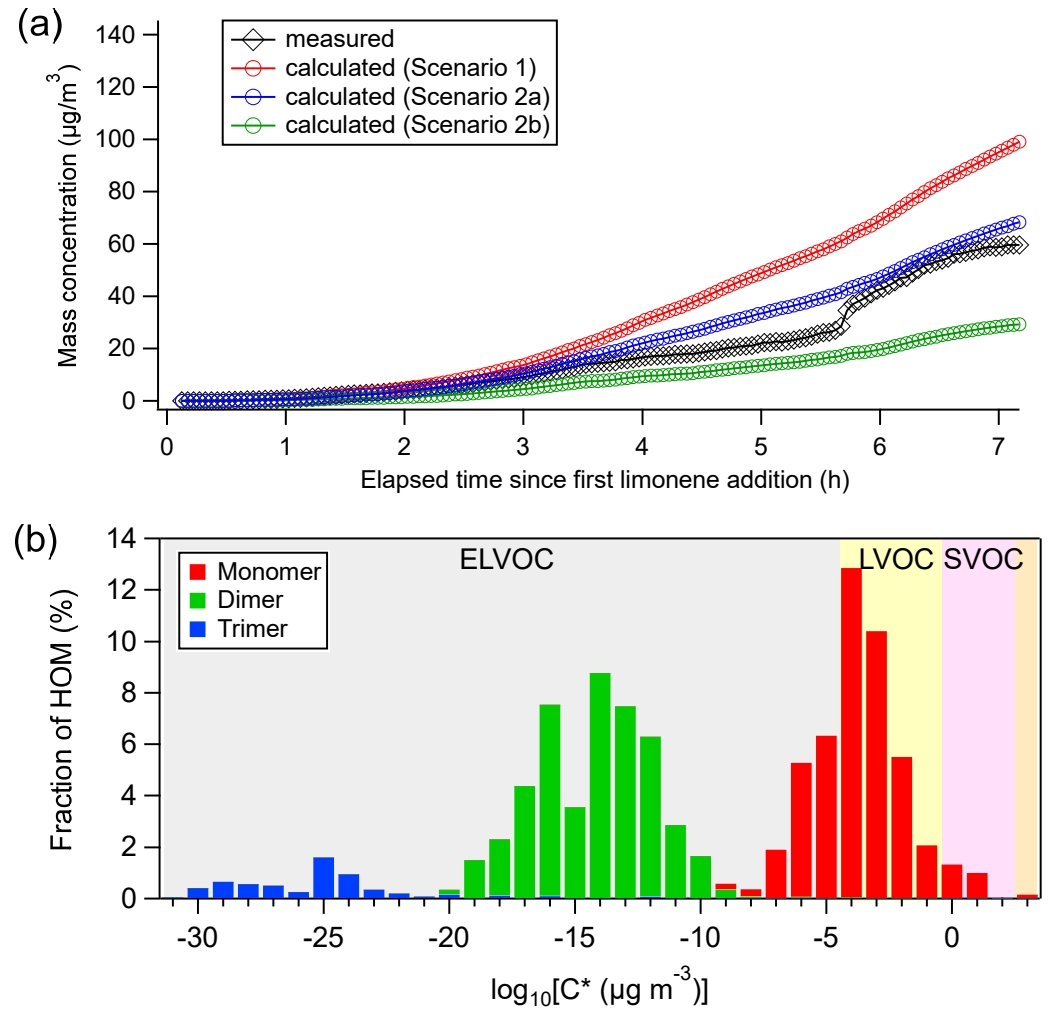

Figure 7. (a) Comparison of measured particle concentrations (black) with those predicted from condensation of measured HOM on aerosol particles, where red markers were calculated under Scenario 1, blue and green markers were calculated under Scenario 2 (only considering the condensation of ELVOC and LVOC) with the volatility calculated using the method by Mohr et al. (2019) (Scenario 2a) and Peräkylä et al. (2020) (Scenario 2b) respectively. (b) HOM volatility distribution using formula provided by Mohr et al. (2019). Average concentrations of HOM in the P1 period were used to calculate the fraction of HOM.

We calculated the contribution of HOM to SOA formation and particle growth and compared it to the measured particle growth (Fig. 7a). We assumed different scenarios of HOM uptake on aerosol particles, using the calculation method in the literature (Ehn et al., 2014; Seinfeld and Pandis, 2006; Nieminen et al., 2010). The assumption that all 
HOM irreversibly condense on the particles (Scenario 1) resulted in a strong overestimation of particle mass growth (red markers in Fig. 7a). Applying the parametrizations of Mohr et al. (2019) (Scenario 2a) or Peräkylä et al. (2020) (Scenario 2b) for classification and accounting only LVOC- and ELVOC-HOM for irreversible uptake framed the observed values (blue and green markers in Fig. 7a). While Scenario 2a agreed quite well with the observations and only slightly overestimated SOA concentration after $7 \mathrm{~h}$ by $+11 \%$, Scenario $2 \mathrm{~b}$ underestimated the SOA concentration at the end by $-53 \%$. The agreement between the modeled and observed SOA concentration suggests that HOM, especially LVOC- and ELVOC-HOM play a major role in SOA growth in this study. According to the work by Faxon et al. (2018), many of the dimers are ELVOC due to their partitioning behavior. This is consistent with our calculation result based on the method of Mohr et al. (2019).

We observed nucleation and SOA growth in the limonene $+\mathrm{NO}_{3}$ reaction. Since neither $\mathrm{SO}_{2}$ nor $\mathrm{H}_{2} \mathrm{SO}_{4}$ was added in our experiment, NPF could be attributed to the nucleation initiated by HOM of low volatility. HOM trimers with as many as 30 carbon atoms were identified in the early stage of this study, and their loss matched the time when rapid formation of SOA occurred. Trimers identified in our experiment are classified as ELVOC, with much lower volatility than monomers and dimers (Fig. 7b). In contrast, in an earlier experiment investigating the $\mathrm{NO}_{3}$-initiated oxidation of $\beta$-pinene also conducted in the SAPHIR chamber under similar conditions, particles were barely formed $\left(<20 \mathrm{~cm}^{-3}\right.$ ) (Shen et al., 2021). As mentioned above, no trimer HOM products were observed in that study, and only molecules with $\mathrm{C} \leq 20$ were detected (Sect. 3.4). Therefore, NPF in our study was likely attributed to HOM trimers since they have the strongest potential of initiating nucleation due to their much lower volatility compared to monomers and dimers. Extremely low volatile organic vapors formed in $\alpha$-pinene ozonolysis have been shown to induce nucleation and drive initial particle growth (Tröstl et al., 2016; Kirkby et al., 2016). Since our experiment of $\mathrm{NO}_{3}$ oxidation of limonene was performed under near atmospheric conditions, such NPF events induced by the oxidation of limonene by $\mathrm{NO}_{3}$ could also occur in the ambient atmosphere. Several field observations have shown NPF events taking place at nighttime where biogenic emissions dominate (Kammer et al., 2018; Huang et al., 2019). The work by Ortega et al. (2012) demonstrated an important role of monoterpene ozonlysis products in nocturnal $\mathrm{NPF}$ events in chamber experiments. In a previous laboratory study, limonene $+\mathrm{NO}_{3}$ appears more effective at initiating nucleation than the limonene $+\mathrm{O}_{3}$ reaction (Fry et al., 2014), which supports that limonene $+\mathrm{NO}_{3}$ can play a significant role in nighttime nucleation. Our study suggests that $\mathrm{NO}_{3}$ oxidation of limonene could contribute to the nighttime NPF via $\mathrm{HOM}$ trimer formation. In contrast, we infer that $\mathrm{NO}_{3}$ reactions with other monoterpenes containing only one double bond such as $\alpha$-pinene and $\beta$-pinene are less likely candidates for nighttime NPF, because gas-phase trimers are not observed. 
HOM formation in the reaction of limonene with $\mathrm{NO}_{3}$ was investigated in the SAPHIR chamber. About 280 gasphase HOM products were identified, including monomers $\left(\mathrm{C}_{6-10}, \mathrm{O}_{6-16}, \mathrm{~N}_{0-3}\right)$, dimers $\left(\mathrm{C}_{17-20}, \mathrm{O}_{7-20}, \mathrm{~N}_{0-4}\right)$ and trimers $\left(\mathrm{C}_{27-30}, \mathrm{O}_{16-25}, \mathrm{~N}_{1-6}\right)$. Nitrogen-containing products dominated the $\mathrm{HOM}$, with compounds of the $\mathrm{C}_{10} \mathrm{H}_{15-17} \mathrm{NO}_{6-14}$ series being the most prevalent. Dimers contributed $47 \%$ in the early stage of the experiment when new particle formation (NPF) had not occurred yet, which was similar to monomers (47\%). Tentative formation pathways of major families were proposed in this work based on their time-dependent concentration profiles.

In HOM monomers, the abundance of carbonyl compounds significantly exceeded that of hydroxyl or hydroperoxy compounds, indicating the significance of unimolecular termination of $\mathrm{HOM}-\mathrm{RO}_{2}$ radicals. Both $\mathrm{RO}_{2}$ • autoxidation and alkoxy-peroxy pathways were found to be important in the formation of HOM monomers. Monomers with 1 nitrogen atom (1N-monomers) contained both first- and second-generation products, which could be formed via $\mathrm{NO}_{3}$ oxidation of limonene and its first-generation products with the latter being more important. Monomers with 2 nitrogen atoms were classified as second-generation products, which could be formed via $\mathrm{NO}_{3}$ oxidation of the remaining $\mathrm{C}=\mathrm{C}$ double bond of $1 \mathrm{~N}$-monomers.

Dimers showed both first- and second-generation time pattern. Dimers were mostly formed via accretion reactions between monomer $\mathrm{RO}_{2}$ radicals, resulting in a decrease in $\mathrm{O} / \mathrm{C}$ ratio compared to monomers. The initial less oxygenated $\mathrm{RO}_{2} \bullet$ such as $\mathrm{C}_{10} \mathrm{H}_{16} \mathrm{O}_{5} \bullet$ likely played an important role in dimer formation based on the comparison of expected dimer identity and concentrations according to accretion monomer $\mathrm{RO}_{2} \bullet$ reactions with measured ones. Trimers were likely formed via accretion reactions between monomer $\mathrm{RO}_{2}$ and dimer $\mathrm{RO}_{2}$ radicals. Trimer formation is attributed to the two double bonds in limonene, which can first react with $\mathrm{NO}_{3}$ leading to dimer products with remaining $\mathrm{C}=\mathrm{C}$ double bond, thus providing reactive site for further oxidation by $\mathrm{NO}_{3}$ forming dimer $\mathrm{RO}_{2}$ radicals.

NPF observed in this work was likely related to the trimer formation due to much lower volatility of trimers compared to monomers and dimers. The SOA concentration in the limonene $+\mathrm{NO}_{3}$ reaction could be explained by the condensation of the HOM belonging to LVOC and ELVOC classes assuming irreversible uptake, suggesting the important role of HOM for SOA growth in this reaction system.

A "primary" HOM molar yield of $1.5 \%_{-0.7}^{+1.7 \%}$ in the limonene $+\mathrm{NO}_{3}$ reaction was estimated, which is much lower than the total HOM yield in the reaction of limonene with ozone (5 to $17 \%$ ) (Ehn et al., 2014; Jokinen et al., 2015; Pagonis et al., 2019). It is worth noting that only first-generation HOM were taken into consideration in our calculation of HOM yield, while second-generation HOM contributed greatly to monomers, dimers and trimers, and 
hence the HOM yield we obtained is a lower limit of the total HOM yield.

To our knowledge, this work is the first identifying trimer products from the limonene $+\mathrm{NO}_{3}$ reaction system, suggesting that limonene $+\mathrm{NO}_{3}$ is a possible crucial source of new particles formed in nighttime biogenic emissiondominated areas (Kammer et al., 2018; Huang et al., 2019). Our work highlights the need to consider the role of limonene $+\mathrm{NO}_{3}$ in NPF in models simulating nighttime aerosols formation in biogenic-emission dominated areas, especially with large limonene emission. In addition, comparison with the reactions of $\mathrm{NO}_{3}$ with isoprene (Zhao et al., 2021) and other monoterpenes (Shen et al., 2021) reveals a strong dependence of HOM products on VOC species in $\mathrm{NO}_{3}$-initiated chemistry.

The concentration of limonene and $\mathrm{NO}_{3}$ in this study were on the order of few ppb and $\sim 100 \mathrm{ppt}$, which is similar to the ambient levels in forest regions affected by anthropogenic emissions (Brown and Stutz, 2012). The chemical lifetime of $\mathrm{NO}_{3}$ was on the order of 50 to $500 \mathrm{~s}$, which is also similar to ambient conditions at nighttime (Fry et al., 2018). The $\mathrm{RO}_{2} \bullet$ loss pathway in our study was dominated by the reactions $\mathrm{RO}_{2} \bullet+\mathrm{NO}_{3}$ and of $\mathrm{RO}_{2} \bullet+\mathrm{RO}_{2} \bullet$, which is representative for the $\mathrm{RO}_{2} \bullet$ fate in urban areas and forested areas influenced by an urban plume. Therefore, the HOM products and their formation process in our study are representative for forested regions influenced by anthropogenic plume and ambient urban regions with high volatile commercial products emissions as limonene is a typical component of volatile chemical products (VCP) (Nazaroff and Weschler, 2004). In these regions, HOM from monoterpene $+\mathrm{NO}_{3}$ reactions can be major components of nighttime SOA.

This study also highlights the important role of second-generation chemistry in HOM formation, which needs to be further investigated and should be included in chemical mechanism used in numerical models. Additional work is also needed to investigate the role of different $\mathrm{HOM}$ formed via $\mathrm{NO}_{3}$-initiated $\mathrm{BVOC}$ oxidation reactions in $\mathrm{NPF}$ and SOA growth in order to better constrain the climatic and environmental effects of BVOC $+\mathrm{NO}_{3}$ chemistry.

\section{Acknowledgement}

Y. Guo, H. Shen, H. Luo, and D. Zhao would like to thank the funding support of Science and Technology Commission of Shanghai Municipality (No. 20230711400), National Natural Science Foundation of China (No. 41875145), and Shanghai International Science and Technology Partnership Project (No. 21230780200). Sungah Kang, Astrid Kiendler-Scharr, and Thomas F. Mentel acknowledge the support by the EU Project FORCeS (grant agreement no. 821205) 
Ayres, B. R., Allen, H. M., Draper, D. C., Brown, S. S., Wild, R. J., Jimenez, J. L., Day, D. A., Campuzano-Jost, P., Hu, W., de Gouw, J., Koss, A., Cohen, R. C., Duffey, K. C., Romer, P., Baumann, K., Edgerton, E., Takahama, S., Thornton, J. A., Lee, B. H., Lopez-Hilfiker, F. D., Mohr, C., Wennberg, P. O., Nguyen, T. B., Teng, A., Goldstein, A. H., Olson, K., and Fry, J. L.: Organic nitrate aerosol formation via $\mathrm{NO}_{3}+$ biogenic volatile organic compounds in the southeastern United States, Atmos. Chem. Phys., 15, 13377-13392, 10.5194/acp-15-13377-2015, 2015.

Beaver, M. R., Clair, J. M. S., Paulot, F., Spencer, K. M., Crounse, J. D., LaFranchi, B. W., Min, K. E., Pusede, S. E., Wooldridge, P. J., Schade, G. W., Park, C., Cohen, R. C., and Wennberg, P. O.: Importance of biogenic precursors to the budget of organic nitrates: observations of multifunctional organic nitrates by CIMS and TD-LIF during BEARPEX 2009, Atmos. Chem. Phys., 12, 5773-5785, 10.5194/acp-12-5773-2012, 2012.

Bell, D. M., Wu, C., Bertrand, A., Graham, E., Schoonbaert, J., Giannoukos, S., Baltensperger, U., Prevot, A. S. H., Riipinen, I., El Haddad, I., and Mohr, C.: Particle-phase processing of $\alpha$-pinene NO3 secondary organic aerosol in the dark, Atmos. Chem. Phys. Discuss., 2021, 1-28, 10.5194/acp-2021-379, 2021.

Berkemeier, T., Takeuchi, M., Eris, G., and Ng, N. L.: Kinetic modeling of formation and evaporation of secondary organic aerosol from $\mathrm{NO}_{3}$ oxidation of pure and mixed monoterpenes, Atmos. Chem. Phys., 20, 15513-15535, 10.5194/acp-20-15513-2020, 2020.

Berndt, T., Mender, B., Scholz, W., Fischer, L., Herrmann, H., Kulmala, M., and Hansel, A.: Accretion Product Formation from Ozonolysis and $\mathrm{OH}$ Radical Reaction of $\alpha$-Pinene: Mechanistic Insight and the Influence of Isoprene and Ethylene, Environ. Sci. Technol., 52, 11069-11077, 10.1021/acs.est.8b02210, 2018a.

Berndt, T., Scholz, W., Mentler, B., Fischer, L., Herrmann, H., Kulmala, M., and Hansel, A.: Accretion Product Formation from Self- and Cross-Reactions of $\mathrm{RO}_{2}$ Radicals in the Atmosphere, Angew. Chem. Int. Edit., 57, 3820-3824, 10.1002/anie.201710989, 2018 b.

Bianchi, F., Kurtén, T., Riva, M., Mohr, C., Rissanen, M. P., Roldin, P., Berndt, T., Crounse, J. D., Wennberg, P. O., Mentel, T. F., Wildt, J., Junninen, H., Jokinen, T., Kulmala, M., Worsnop, D. R., Thornton, J. A., Donahue, N., Kjaergaard, H. G., and Ehn, M.: Highly Oxygenated Organic Molecules (HOM) from Gas-Phase Autoxidation Involving Peroxy Radicals: A Key Contributor to Atmospheric Aerosol, Chem. Rev., 119, 3472-3509, 10.1021/acs.chemrev.8b00395, 2019.

Boyd, C. M., Nah, T., Xu, L., Berkemeier, T., and Ng, N. L.: Secondary Organic Aerosol (SOA) from Nitrate Radical Oxidation of Monoterpenes: Effects of Temperature, Dilution, and Humidity on Aerosol Formation, Mixing, and Evaporation, Environ. Sci. Technol., 51, 7831-7841, 10.1021/acs.est.7b01460, 2017.

Boyd, C. M., Sanchez, J., Xu, L., Eugene, A. J., Nah, T., Tuet, W. Y., Guzman, M. I., and Ng, N. L.: Secondary organic aerosol formation from the $\beta$-pinene $+\mathrm{NO}_{3}$ system: effect of humidity and peroxy radical fate, Atmos. Chem. Phys., 15, 7497-7522, 10.5194/acp-15-7497-2015, 2015.

Brown, S. S. and Stutz, J.: Nighttime radical observations and chemistry, Chem. Soc. Rev., 41, 6405-6447, 10.1039/c2cs35181a, 2012.

Carslaw, N., Mota, T., Jenkin, M. E., Barley, M. H., and McFiggans, G.: A significant role for nitrate and peroxide groups on indoor secondary organic aerosol, Environ. Sci. Technol., 46, 9290-9298, 10.1021/es301350x, 2012.

Chen, Y., Takeuchi, M., Nah, T., Xu, L., Canagaratna, M. R., Stark, H., Baumann, K., Canonaco, F., Prévôt, A. S. H., Huey, L. G., Weber, R. J., and Ng, N. L.: Chemical characterization of secondary organic aerosol at a rural site in the southeastern US: insights from simultaneous high-resolution time-of-flight aerosol mass spectrometer (HR-ToF-AMS) and FIGAERO chemical ionization mass spectrometer (CIMS) measurements, Atmos. Chem. Phys., 20, 8421-8440, 10.5194/acp-20-8421-2020, 2020.

Claflin, M. S. and Ziemann, P. J.: Identification and Quantitation of Aerosol Products of the Reaction of $\beta$-Pinene with $\mathrm{NO}_{3} \mathrm{Radical}_{\mathrm{s}}$ and Implications for Gas- and Particle-Phase Reaction Mechanisms, J. Phys. Chem. A, 122, 3640-3652, 10.1021/acs.jpca.8b00692, 2018.

Clausen, P. A., Wilkins, C. K., Wolkoff, P., and Nielsen, G. D.: Chemical and biological evaluation of a reaction mixture of R-(+)limonene/ozone - Formation of strong airway irritants, Environ. Int., 26, 511-522, 10.1016/s0160-4120(01)00035-6, 2001.

Crounse, J. D., Nielsen, L. B., Jørgensen, S., Kjaergaard, H. G., and Wennberg, P. O.: Autoxidation of Organic Compounds in the 
Donahue, N. M., Epstein, S. A., Pandis, S. N., and Robinson, A. L.: A two-dimensional volatility basis set: 1. organic-aerosol mixing thermodynamics, Atmos. Chem. Phys., 11, 3303-3318, 10.5194/acp-11-3303-2011, 2011.

Donahue, N. M., Kroll, J. H., Pandis, S. N., and Robinson, A. L.: A two-dimensional volatility basis set - Part 2: Diagnostics of organic-aerosol evolution, Atmos. Chem. Phys., 12, 615-634, 10.5194/acp-12-615-2012, 2012.

Ehn, M., Thornton, J. A., Kleist, E., Sipilä, M., Junninen, H., Pullinen, I., Springer, M., Rubach, F., Tillmann, R., Lee, B., LopezHilfiker, F., Andres, S., Acir, I. H., Rissanen, M., Jokinen, T., Schobesberger, S., Kangasluoma, J., Kontkanen, J., Nieminen, T., Kurtén, T., Nielsen, L. B., Jørgensen, S., Kjaergaard, H. G., Canagaratna, M., Dal Maso, M., Berndt, T., Petäjä, T., Wahner, A., Kerminen, V. M., Kulmala, M., Worsnop, D. R., Wildt, J., and Mentel, T. F.: A large source of low-volatility secondary organic aerosol, Nature, 506, 476-485, 10.1038/nature13032, 2014.

Eisele, F. L. and Tanner, D. J.: Measurement of the gas phase concentration of $\mathrm{H}_{2} \mathrm{SO}_{4}$ and methane sulfonic acid and estimates of $\mathrm{H}_{2} \mathrm{SO}_{4}$ production and loss in the atmosphere, J. Geophys. Res.-Atmos., 98, 9001-9010, 10.1029/93jd00031, 1993.

Fan, Z. H., Lioy, P., Weschler, C., Fiedler, N., Kipen, H., and Zhang, J. F.: Ozone-initiated reactions with mixtures of volatile organic compounds under simulated indoor conditions, Environ. Sci. Technol., 37, 1811-1821, 10.1021/es026231i, 2003.

Faxon, C., Hammes, J., Le Breton, M., Pathak, R. K., and Hallquist, M.: Characterization of organic nitrate constituents of secondary organic aerosol (SOA) from nitrate-radical-initiated oxidation of limonene using high-resolution chemical ionization mass spectrometry, Atmos. Chem. Phys., 18, 5467-5481, 10.5194/acp-18-5467-2018, 2018.

Finlayson-Pitts, B. J. and Pitts, J. N.: Tropospheric air pollution: Ozone, airborne toxics, polycyclic aromatic hydrocarbons, and particles, Science, 276, 1045-1052, 10.1126/science.276.5315.1045, 1997.

Fry, J. L., Draper, D. C., Barsanti, K. C., Smith, J. N., Ortega, J., Winkler, P. M., Lawler, M. J., Brown, S. S., Edwards, P. M., Cohen, R. C., and Lee, L.: Secondary organic aerosol formation and organic nitrate yield from $\mathrm{NO}_{3}$ oxidation of biogenic hydrocarbons, Environ. Sci. Technol., 48, 11944-11953, 10.1021/es502204x, 2014.

Fry, J. L., Kiendler-Scharr, A., Rollins, A. W., Brauers, T., Brown, S. S., Dorn, H. P., Dubé, W. P., Fuchs, H., Mensah, A., Rohrer, F., Tillmann, R., Wahner, A., Wooldridge, P. J., and Cohen, R. C.: SOA from limonene: role of $\mathrm{NO}_{3}$ in its generation and degradation, Atmos. Chem. Phys., 11, 3879-3894, 10.5194/acp-11-3879-2011, 2011.

Fry, J. L., Draper, D. C., Zarzana, K. J., Campuzano-Jost, P., Day, D. A., Jimenez, J. L., Brown, S. S., Cohen, R. C., Kaser, L., Hansel, A., Cappellin, L., Karl, T., Hodzic Roux, A., Turnipseed, A., Cantrell, C., Lefer, B. L., and Grossberg, N.: Observations of gas- and aerosol-phase organic nitrates at BEACHON-RoMBAS 2011, Atmos. Chem. Phys., 13, 8585-8605, 10.5194/acp13-8585-2013, 2013.

Fry, J. L., Brown, S. S., Middlebrook, A. M., Edwards, P. M., Campuzano-Jost, P., Day, D. A., Jimenez, J. L., Allen, H. M., Ryerson, T. B., Pollack, I., Graus, M., Warneke, C., de Gouw, J. A., Brock, C. A., Gilman, J., Lerner, B. M., Dubé, W. P., Liao, J., and Welti, A.: Secondary organic aerosol (SOA) yields from $\mathrm{NO}_{3}$ radical + isoprene based on nighttime aircraft power plant plume transects, Atmos. Chem. Phys., 18, 11663-11682, 10.5194/acp-18-11663-2018, 2018.

Fuchs, N. A. and Sutugin, A. G.: Topics in Current Aerosol Research (Part 2), Pergamon, New York, 1971.

Gkatzelis, G. I., Coggon, M. M., McDonald, B. C., Peischl, J., Aikin, K. C., Gilman, J. B., Trainer, M., and Warneke, C.: Identifying Volatile Chemical Product Tracer Compounds in U.S. Cities, Environ. Sci. Technol., 55, 188-199, 10.1021/acs.est.0c05467, 2021.

Guenther, A. B., Jiang, X., Heald, C. L., Sakulyanontvittaya, T., Duhl, T., Emmons, L. K., and Wang, X.: The Model of Emissions of Gases and Aerosols from Nature version 2.1 (MEGAN2.1): an extended and updated framework for modeling biogenic emissions, Geosci. Model Dev., 5, 1471-1492, 10.5194/gmd-5-1471-2012, 2012.

Hallquist, M., Wängberg, I., Ljungström, E., Barnes, I., and Becker, K. H.: Aerosol and product yields from $\mathrm{NO}_{3}$ radical-initiated oxidation of selected monoterpenes, Environ. Sci. Technol., 33, 553-559, 10.1021/es980292s, 1999.

Hallquist, M., Wenger, J. C., Baltensperger, U., Rudich, Y., Simpson, D., Claeys, M., Dommen, J., Donahue, N. M., George, C., Goldstein, A. H., Hamilton, J. F., Herrmann, H., Hoffmann, T., Iinuma, Y., Jang, M., Jenkin, M. E., Jimenez, J. L., KiendlerScharr, A., Maenhaut, W., McFiggans, G., Mentel, T. F., Monod, A., Prévôt, A. S. H., Seinfeld, J. H., Surratt, J. D., Szmigielski, R., and Wildt, J.: The formation, properties and impact of secondary organic aerosol: current and emerging issues, Atmos. Chem. Phys., 9, 5155-5236, 10.5194/acp-9-5155-2009, 2009. 
Huang, W., Saathoff, H., Shen, X., Ramisetty, R., Leisner, T., and Mohr, C.: Chemical Characterization of Highly Functionalized Organonitrates Contributing to Night-Time Organic Aerosol Mass Loadings and Particle Growth, Environ. Sci. Technol., 53, 1165-1174, 10.1021/acs.est.8b05826, 2019.

Jiang, L., Wang, W., and Xu, Y. S.: Theoretical investigation of the $\mathrm{NO}_{3}$ radical addition to double bonds of limonene, Int. J. Mol. Sci., 10, 3743-3754, 10.3390/ijms10093743, 2009.

Jokinen, T., Sipilä, M., Junninen, H., Ehn, M., Lönn, G., Hakala, J., Petäjä, T., Mauldin, R. L., Kulmala, M., and Worsnop, D. R.: Atmospheric sulphuric acid and neutral cluster measurements using CI-APi-TOF, Atmos. Chem. Phys., 12, 4117-4125, 10.5194/acp-12-4117-2012, 2012.

Jokinen, T., Berndt, T., Makkonen, R., Kerminen, V. M., Junninen, H., Paasonen, P., Stratmann, F., Herrmann, H., Guenther, A. B., Worsnop, D. R., Kulmala, M., Ehn, M., and Sipilä, M.: Production of extremely low volatile organic compounds from biogenic emissions: Measured yields and atmospheric implications, P. Natl. Acad. Sci. USA, 112, 7123-7128, 10.1073/pnas.1423977112, 2015.

Kammer, J., Perraudin, E., Flaud, P. M., Lamaud, E., Bonnefond, J. M., and Villenave, E.: Observation of nighttime new particle formation over the French Landes forest, Sci. Total Environ., 621, 1084-1092, 10.1016/j.scitotenv.2017.10.118, 2018.

Kirkby, J., Duplissy, J., Sengupta, K., Frege, C., Gordon, H., Williamson, C., Heinritzi, M., Simon, M., Yan, C., Almeida, J., Tröstl, J., Nieminen, T., Ortega, I. K., Wagner, R., Adamov, A., Amorim, A., Bernhammer, A. K., Bianchi, F., Breitenlechner, M., Brilke, S., Chen, X., Craven, J., Dias, A., Ehrhart, S., Flagan, R. C., Franchin, A., Fuchs, C., Guida, R., Hakala, J., Hoyle, C. R., Jokinen, T., Junninen, H., Kangasluoma, J., Kim, J., Krapf, M., Kürten, A., Laaksonen, A., Lehtipalo, K., Makhmutov, V., Mathot, S., Molteni, U., Onnela, A., Peräkylä, O., Piel, F., Petäjä, T., Praplan, A. P., Pringle, K., Rap, A., Richards, N. A., Riipinen, I., Rissanen, M. P., Rondo, L., Sarnela, N., Schobesberger, S., Scott, C. E., Seinfeld, J. H., Sipilä, M., Steiner, G., Stozhkov, Y., Stratmann, F., Tomé, A., Virtanen, A., Vogel, A. L., Wagner, A. C., Wagner, P. E., Weingartner, E., Wimmer, D., Winkler, P. M., Ye, P., Zhang, X., Hansel, A., Dommen, J., Donahue, N. M., Worsnop, D. R., Baltensperger, U., Kulmala, M., Carslaw, K. S., and Curtius, J.: Ion-induced nucleation of pure biogenic particles, Nature, 533, 521-526, 10.1038/nature17953, 2016.

Klinger, L. F., Li, Q. J., Guenther, A. B., Greenberg, J. P., Baker, B., and Bai, J. H.: Assessment of volatile organic compound emissions from ecosystems of China, J. Geophys. Res.-Atmos., 107, 10.1029/2001jd001076, 2002.

Kurtén, T., Møller, K. H., Nguyen, T. B., Schwantes, R. H., Misztal, P. K., Su, L., Wennberg, P. O., Fry, J. L., and Kjaergaard, H. G.: Alkoxy Radical Bond Scissions Explain the Anomalously Low Secondary Organic Aerosol and Organonitrate Yields From $\alpha$-Pinene $+\mathrm{NO}_{3}$, J. Phys. Chem. Lett., 8, 2826-2834, 10.1021/acs.jpclett.7b01038, 2017.

Lee, B. H., Mohr, C., Lopez-Hilfiker, F. D., Lutz, A., Hallquist, M., Lee, L., Romer, P., Cohen, R. C., Iyer, S., Kurten, T., Hu, W., Day, D. A., Campuzano-Jost, P., Jimenez, J. L., Xu, L., Ng, N. L., Guo, H., Weber, R. J., Wild, R. J., Brown, S. S., Koss, A., de Gouw, J., Olson, K., Goldstein, A. H., Seco, R., Kim, S., McAvey, K., Shepson, P. B., Starn, T., Baumann, K., Edgerton, E. S., Liu, J., Shilling, J. E., Miller, D. O., Brune, W., Schobesberger, S., D'Ambro, E. L., and Thornton, J. A.: Highly functionalized organic nitrates in the southeast United States: Contribution to secondary organic aerosol and reactive nitrogen budgets, P. Natl. Acad. Sci. USA, 113, 1516-1521, 10.1073/pnas.1508108113, 2016.

Massoli, P., Stark, H., Canagaratna, M. R., Krechmer, J. E., Xu, L., Ng, N. L., Mauldin, R. L., Yan, C., Kimmel, J., Misztal, P. K., Jimenez, J. L., Jayne, J. T., and Worsnop, D. R.: Ambient Measurements of Highly Oxidized Gas-Phase Molecules during the Southern Oxidant and Aerosol Study (SOAS) 2013, ACS Earth and Space Chemistry, 2, 653-672, 10.1021/acsearthspacechem.8b00028, 2018.

McDonald, B. C., de Gouw, J. A., Gilman, J. B., Jathar, S. H., Akherati, A., Cappa, C. D., Jimenez, J. L., Lee-Taylor, J., Hayes, P. L., McKeen, S. A., Cui, Y. Y., Kim, S.-W., Gentner, D. R., Isaacman-VanWertz, G., Goldstein, A. H., Harley, R. A., Frost, G. J., Roberts, J. M., Ryerson, T. B., and Trainer, M.: Volatile chemical products emerging as largest petrochemical source of urban organic emissions, Science, 359, 760-764, 10.1126/science.aaq0524, 2018.

McFiggans, G., Mentel, T. F., Wildt, J., Pullinen, I., Kang, S., Kleist, E., Schmitt, S., Springer, M., Tillmann, R., Wu, C., Zhao, D. F., Hallquist, M., Faxon, C., Le Breton, M., Hallquist, A. M., Simpson, D., Bergström, R., Jenkin, M. E., Ehn, M., Thornton, J. A., Alfarra, M. R., Bannan, T. J., Percival, C. J., Priestley, M., Topping, D., and Kiendler-Scharr, A.: Secondary organic aerosol reduced by mixture of atmospheric vapours, Nature, 565, 587-593, 10.1038/s41586-018-0871-y, 2019. 
Mentel, T. F., Springer, M., Ehn, M., Kleist, E., Pullinen, I., Kurtén, T., Rissanen, M., Wahner, A., and Wildt, J.: Formation of highly oxidized multifunctional compounds: autoxidation of peroxy radicals formed in the ozonolysis of alkenes - deduced from structure-product relationships, Atmos. Chem. Phys., 15, 6745-6765, 10.5194/acp-15-6745-2015, 2015.

Mohr, C., Thornton, J. A., Heitto, A., Lopez-Hilfiker, F. D., Lutz, A., Riipinen, I., Hong, J., Donahue, N. M., Hallquist, M., Petäjä, T., Kulmala, M., and Yli-Juuti, T.: Molecular identification of organic vapors driving atmospheric nanoparticle growth, Nat. Commun., 10, 4442, https://doi.org/10.1038/s41467-019-12473-2, 2019.

Mutzel, A., Zhang, Y., Böge, O., Rodigast, M., Kolodziejczyk, A., Wang, X., and Herrmann, H.: Importance of secondary organic aerosol formation of $\alpha$-pinene, limonene, and $\mathrm{m}$-cresol comparing day- and nighttime radical chemistry, Atmos. Chem. Phys., 21, 8479-8498, 10.5194/acp-21-8479-2021, 2021.

Nah, T., Sanchez, J., Boyd, C. M., and Ng, N. L.: Photochemical Aging of $\alpha$-pinene and $\beta$-pinene Secondary Organic Aerosol formed from Nitrate Radical Oxidation, Environ. Sci. Technol., 50, 222-231, 10.1021/acs.est.5b04594, 2016.

Nazaroff, W. W. and Weschler, C. J.: Cleaning products and air fresheners: exposure to primary and secondary air pollutants, Atmos. Environ., 38, 2841-2865, 10.1016/j.atmosenv.2004.02.040, 2004.

Ng, N. L., Kwan, A. J., Surratt, J. D., Chan, A. W. H., Chhabra, P. S., Sorooshian, A., Pye, H. O. T., Crounse, J. D., Wennberg, P. O., Flagan, R. C., and Seinfeld, J. H.: Secondary organic aerosol (SOA) formation from reaction of isoprene with nitrate radicals $\left(\mathrm{NO}_{3}\right)$, Atmos. Chem. Phys., 8, 4117-4140, 10.5194/acp-8-4117-2008, 2008.

Nieminen, T., Lehtinen, K. E. J., and Kulmala, M.: Sub-10 nm particle growth by vapor condensation - effects of vapor molecule size and particle thermal speed, Atmos. Chem. Phys., 10, 9773-9779, 10.5194/acp-10-9773-2010, 2010.

Novelli, A., Cho, C., Fuchs, H., Hofzumahaus, A., Rohrer, F., Tillmann, R., Kiendler-Scharr, A., Wahner, A., and Vereecken, L.: Experimental and theoretical study on the impact of a nitrate group on the chemistry of alkoxy radicals, Phys. Chem. Chem. Phys., 23, 5474-5495, 10.1039/d0cp05555g, 2021.

Ortega, I. K., Suni, T., Boy, M., Grönholm, T., Manninen, H. E., Nieminen, T., Ehn, M., Junninen, H., Hakola, H., Hellén, H., Valmari, T., Arvela, H., Zegelin, S., Hughes, D., Kitchen, M., Cleugh, H., Worsnop, D. R., Kulmala, M., and Kerminen, V. M.: New insights into nocturnal nucleation, Atmos. Chem. Phys., 12, 4297-4312, 10.5194/acp-12-4297-2012, 2012.

Pagonis, D., Algrim, L. B., Price, D. J., Day, D. A., Handschy, A. V., Stark, H., Miller, S. L., de Gouw, J. A., Jimenez, J. L., and Ziemann, P. J.: Autoxidation of Limonene Emitted in a University Art Museum, Environ. Sci. Tech. Let., 6, 520-524, 10.1021/acs.estlett.9b00425, 2019.

Peng, C., Wang, W., Li, K., Li, J., Zhou, L., Wang, L., and Ge, M.: The Optical Properties of Limonene Secondary Organic Aerosols: The Role of NO3, OH, and $\mathrm{O} 3$ in the Oxidation Processes, J. Geophys. Res.-Atmos., 123, 3292-3303, https://doi.org/10.1002/2017JD028090, 2018.

Peräkylä, O., Riva, M., Heikkinen, L., Quéléver, L., Roldin, P., and Ehn, M.: Experimental investigation into the volatilities of highly oxygenated organic molecules (HOMs), Atmos. Chem. Phys., 20, 649-669, 10.5194/acp-20-649-2020, 2020.

Pullinen, I., Schmitt, S., Kang, S., Sarrafzadeh, M., Schlag, P., Andres, S., Kleist, E., Mentel, T. F., Rohrer, F., Springer, M., Tillmann, R., Wildt, J., Wu, C., Zhao, D., Wahner, A., and Kiendler-Scharr, A.: Impact of $\mathrm{NO}_{\mathrm{x}}$ on secondary organic aerosol (SOA) formation from $\alpha$-pinene and $\beta$-pinene photooxidation: the role of highly oxygenated organic nitrates, Atmos. Chem. Phys., 20, 10125-10147, 10.5194/acp-20-10125-2020, 2020.

Pye, H. O. T., Chan, A. W. H., Barkley, M. P., and Seinfeld, J. H.: Global modeling of organic aerosol: the importance of reactive nitrogen $\left(\mathrm{NO}_{\mathrm{x}}\right.$ and $\left.\mathrm{NO}_{3}\right)$, Atmos. Chem. Phys., 10, 11261-11276, 10.5194/acp-10-11261-2010, 2010.

Rissanen, M. P., Kurtén, T., Sipilä, M., Thornton, J. A., Kangasluoma, J., Sarnela, N., Junninen, H., Jørgensen, S., Schallhart, S., Kajos, M. K., Taipale, R., Springer, M., Mentel, T. F., Ruuskanen, T., Petäjä, T., Worsnop, D. R., Kjaergaard, H. G., and Ehn, M.: The formation of highly oxidized multifunctional products in the ozonolysis of cyclohexene, J. Am. Chem. Soc., 136, 15596-15606, 10.1021/ja507146s, 2014.

Riva, M., Heikkinen, L., Bell, D. M., Peräkylä, O., Zha, Q., Schallhart, S., Rissanen, M. P., Imre, D., Petäjä, T., Thornton, J. A., Zelenyuk, A., and Ehn, M.: Chemical transformations in monoterpene-derived organic aerosol enhanced by inorganic composition, Npj Climate and Atmospheric Science, 2, 10.1038/s41612-018-0058-0, 2019.

Rohrer, F., Bohn, B., Brauers, T., Brüning, D., Johnen, F. J., Wahner, A., and Kleffmann, J.: Characterisation of the photolytic HONO-source in the atmosphere simulation chamber SAPHIR, Atmos. Chem. Phys., 5, 2189-2201, 10.5194/acp-5-2189-2005, 
2005.

Rollins, A. W., Kiendler-Scharr, A., Fry, J. L., Brauers, T., Brown, S. S., Dorn, H. P., Dubé, W. P., Fuchs, H., Mensah, A., Mentel, T. F., Rohrer, F., Tillmann, R., Wegener, R., Wooldridge, P. J., and Cohen, R. C.: Isoprene oxidation by nitrate radical: alkyl nitrate and secondary organic aerosol yields, Atmos. Chem. Phys., 9, 6685-6703, 10.5194/acp-9-6685-2009, 2009.

Rollins, A. W. B., E. C.; Min, K.-E.; Pusede, S. E.; Wooldridge, P. J.; Gentner, D. R.; Goldstein, A. H.; Liu, S.; Day, D. A.; Russell, L. M.; Cohen, R. C.: Evidence for $\mathrm{NO}_{\mathrm{x}}$ control over nighttime SOA formation, Science, 337, 1210-1212, 10.1126/science.1221520, 2012.

Saunders, S. M., Jenkin, M. E., Derwent, R. G., and Pilling, M. J.: Protocol for the development of the Master Chemical Mechanism, MCM v3 (Part A): tropospheric degradation of non-aromatic volatile organic compounds, Atmos. Chem. Phys., 3, 161-180, 10.5194/acp-3-161-2003, 2003.

Seinfeld, J. H. and Pandis, S. N.: Atmospheric Chemistry and Physics: From Air Pollution to Climate Change, 2nd ed, Wiley, John \& Sons, New York, 2006.

Shen, H., Zhao, D., Pullinen, I., Kang, S., Vereecken, L., Fuchs, H., Acir, I.-H., Tillmann, R., Rohrer, F., Wildt, J., Kiendler-Scharr, A., Wahner, A., and Mentel, T. F.: Highly Oxygenated Organic Nitrates Formed from $\mathrm{NO}_{3}$ Radical-Initiated Oxidation of $\beta$ Pinene, Environ. Sci. Technol., 10.1021/acs.est.1c03978, 2021.

Shrivastava, M., Cappa, C. D., Fan, J., Goldstein, A. H., Guenther, A. B., Jimenez, J. L., Kuang, C., Laskin, A., Martin, S. T., Ng, N. L., Petäjä, T., Pierce, J. R., Rasch, P. J., Roldin, P., Seinfeld, J. H., Shilling, J., Smith, J. N., Thornton, J. A., Volkamer, R., Wang, J., Worsnop, D. R., Zaveri, R. A., Zelenyuk, A., and Zhang, Q.: Recent advances in understanding secondary organic aerosol: Implications for global climate forcing, Rev. Geophys., 55, 509-559, 10.1002/2016rg000540, 2017.

Slade, J. H., de Perre, C., Lee, L., and Shepson, P. B.: Nitrate radical oxidation of $\gamma$-terpinene: hydroxy nitrate, total organic nitrate, and secondary organic aerosol yields, Atmos. Chem. Phys., 17, 8635-8650, 10.5194/acp-17-8635-2017, 2017.

Spittler, M., Barnes, I., Bejan, I., Brockmann, K. J., Benter, T., and Wirtz, K.: Reactions of $\mathrm{NO}_{3}$ radicals with limonene and $\alpha$-pinene: Product and SOA formation, Atmos. Environ., 40, 116-127, 10.1016/j.atmosenv.2005.09.093, 2006.

Takeuchi, M. and Ng, N. L.: Chemical composition and hydrolysis of organic nitrate aerosol formed from hydroxyl and nitrate radical oxidation of $\alpha$-pinene and $\beta$-pinene, Atmos. Chem. Phys., 19, 12749-12766, 10.5194/acp-19-12749-2019, 2019.

Tröstl, J., Chuang, W. K., Gordon, H., Heinritzi, M., Yan, C., Molteni, U., Ahlm, L., Frege, C., Bianchi, F., Wagner, R., Simon, M., Lehtipalo, K., Williamson, C., Craven, J. S., Duplissy, J., Adamov, A., Almeida, J., Bernhammer, A. K., Breitenlechner, M., Brilke, S., Dias, A., Ehrhart, S., Flagan, R. C., Franchin, A., Fuchs, C., Guida, R., Gysel, M., Hansel, A., Hoyle, C. R., Jokinen, T., Junninen, H., Kangasluoma, J., Keskinen, H., Kim, J., Krapf, M., Kürten, A., Laaksonen, A., Lawler, M., Leiminger, M., Mathot, S., Möhler, O., Nieminen, T., Onnela, A., Petäjä, T., Piel, F. M., Miettinen, P., Rissanen, M. P., Rondo, L., Sarnela, N., Schobesberger, S., Sengupta, K., Sipilä, M., Smith, J. N., Steiner, G., Tomè, A., Virtanen, A., Wagner, A. C., Weingartner, E., Wimmer, D., Winkler, P. M., Ye, P., Carslaw, K. S., Curtius, J., Dommen, J., Kirkby, J., Kulmala, M., Riipinen, I., Worsnop, D. R., Donahue, N. M., and Baltensperger, U.: The role of low-volatility organic compounds in initial particle growth in the atmosphere, Nature, 533, 527-531, 10.1038/nature18271, 2016.

Vereecken, L. and Nozière, B.: H migration in peroxy radicals under atmospheric conditions, Atmos. Chem. Phys., 20, 7429-7458, 10.5194/acp-20-7429-2020, 2020.

Vereecken, L. and Peeters, J.: A structure-activity relationship for the rate coefficient of H-migration in substituted alkoxy radicals, Phys. Chem. Chem. Phys., 12, 12608-12620, 10.1039/c0cp00387e, 2010.

Wagner, N. L., Dubé, W. P., Washenfelder, R. A., Young, C. J., Pollack, I. B., Ryerson, T. B., and Brown, S. S.: Diode laser-based cavity ring-down instrument for $\mathrm{NO}_{3}, \mathrm{~N}_{2} \mathrm{O}_{5}, \mathrm{NO}, \mathrm{NO}_{2}$ and $\mathrm{O}_{3}$ from aircraft, Atmos. Meas. Tech., 4, 1227-1240, 10.5194/amt4-1227-2011, 2011.

Wang, S. and Pratt, K. A.: Molecular Halogens Above the Arctic Snowpack: Emissions, Diurnal Variations, and Recycling Mechanisms, J. Geophys. Res.-Atmos., 122, 11991-12007, 10.1002/2017jd027175, 2017.

Wu, C., Bell, D. M., Graham, E. L., Haslett, S., Riipinen, I., Baltensperger, U., Bertrand, A., Giannoukos, S., Schoonbaert, J., El Haddad, I., Prevot, A. S. H., Huang, W., and Mohr, C.: Photolytically induced changes in composition and volatility of biogenic secondary organic aerosol from nitrate radical oxidation during night-to-day transition, Atmos. Chem. Phys., 21, 14907-14925, 10.5194/acp-21-14907-2021, 2021a. 
Wu, R., Vereecken, L., Tsiligiannis, E., Kang, S., Albrecht, S. R., Hantschke, L., Zhao, D., Novelli, A., Fuchs, H., Tillmann, R., Hohaus, T., Carlsson, P. T. M., Shenolikar, J., Bernard, F., Crowley, J. N., Fry, J. L., Brownwood, B., Thornton, J. A., Brown, S. S., Kiendler-Scharr, A., Wahner, A., Hallquist, M., and Mentel, T. F.: Molecular composition and volatility of multigeneration products formed from isoprene oxidation by nitrate radical, Atmos. Chem. Phys., 21, 10799-10824, 10.5194/acp21-10799-2021, 2021b.

Xu, L., Guo, H., Boyd, C. M., Klein, M., Bougiatioti, A., Cerully, K. M., Hite, J. R., Isaacman-VanWertz, G., Kreisberg, N. M., Knote, C., Olson, K., Koss, A., Goldstein, A. H., Hering, S. V., de Gouw, J., Baumann, K., Lee, S.-H., Nenes, A., Weber, R. J., and $\mathrm{Ng}$, N. L.: Effects of anthropogenic emissions on aerosol formation from isoprene and monoterpenes in the southeastern United States, P. Natl. Acad. Sci. USA, 112, 37-42, 10.1073/pnas.1417609112, 2015.

Zhang, H., Yee, L. D., Lee, B. H., Curtis, M. P., Worton, D. R., Isaacman-VanWertz, G., Offenberg, J. H., Lewandowski, M., Kleindienst, T. E., Beaver, M. R., Holder, A. L., Lonneman, W. A., Docherty, K. S., Jaoui, M., Pye, H. O. T., Hu, W., Day, D. A., Campuzano-Jost, P., Jimenez, J. L., Guo, H., Weber, R. J., de Gouw, J., Koss, A. R., Edgerton, E. S., Brune, W., Mohr, C., Lopez-Hilfiker, F. D., Lutz, A., Kreisberg, N. M., Spielman, S. R., Hering, S. V., Wilson, K. R., Thornton, J. A., and Goldstein, A. H.: Monoterpenes are the largest source of summertime organic aerosol in the southeastern United States, P. Natl. Acad. Sci. USA, 115, 2038-2043, 10.1073/pnas.1717513115, 2018.

Zhao, D., Pullinen, I., Fuchs, H., Schrade, S., Wu, R., Acir, I.-H., Tillmann, R., Rohrer, F., Wildt, J., Guo, Y., Kiendler-Scharr, A., Wahner, A., Kang, S., Vereecken, L., and Mentel, T. F.: Highly oxygenated organic molecule (HOM) formation in the isoprene oxidation by $\mathrm{NO}_{3}$ radical, Atmos. Chem. Phys., 21, 9681-9704, 10.5194/acp-21-9681-2021, 2021.

Zhao, D., Schmitt, S. H., Wang, M., Acir, I.-H., Tillmann, R., Tan, Z., Novelli, A., Fuchs, H., Pullinen, I., Wegener, R., Rohrer, F., Wildt, J., Kiendler-Scharr, A., Wahner, A., and Mentel, T. F.: Effects of $\mathrm{NO}_{\mathrm{x}}$ and $\mathrm{SO}_{2}$ on the secondary organic aerosol formation from photooxidation of $\alpha$-pinene and limonene, Atmos. Chem. Phys., 18, 1611-1628, 10.5194/acp-18-1611-2018, 2018.

Zhao, D. F., Buchholz, A., Kortner, B., Schlag, P., Rubach, F., Kiendler-Scharr, A., Tillmann, R., Wahner, A., Flores, J. M., Rudich,

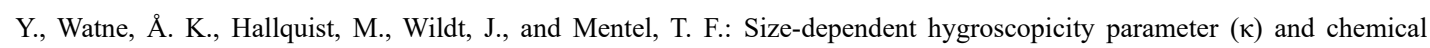
composition of secondary organic cloud condensation nuclei, Geophys. Res. Lett., 42, 10920-10928, 10.1002/2015gl066497, $2015 \mathrm{a}$.

Zhao, D. F., Kaminski, M., Schlag, P., Fuchs, H., Acir, I. H., Bohn, B., Häseler, R., Kiendler-Scharr, A., Rohrer, F., Tillmann, R., Wang, M. J., Wegener, R., Wildt, J., Wahner, A., and Mentel, T. F.: Secondary organic aerosol formation from hydroxyl radical oxidation and ozonolysis of monoterpenes, Atmos. Chem. Phys., 15, 991-1012, 10.5194/acp-15-991-2015, 2015 b.

Zhou, L., Gierens, R., Sogachev, A., Mogensen, D., Ortega, J., Smith, J. N., Harley, P. C., Prenni, A. J., Levin, E. J. T., Turnipseed, A., Rusanen, A., Smolander, S., Guenther, A. B., Kulmala, M., Karl, T., and Boy, M.: Contribution from biogenic organic compounds to particle growth during the 2010 BEACHON-ROCS campaign in a Colorado temperate needleleaf forest, Atmos. Chem. Phys., 15, 8643-8656, 10.5194/acp-15-8643-2015, 2015.

Ziemann, P. J. and Atkinson, R.: Kinetics, products, and mechanisms of secondary organic aerosol formation, Chem. Soc. Rev., 41, 6582-6605, 10.1039/c2cs35122f, 2012. 